Revue de sciences sociales sur les arts, la culture et les idées

4 | 2019

Autonomies des arts et de la culture

\title{
Indépendance et autonomie
}

Des usages rhétoriques de quelques notions ambivalentes dans le secteur du livre en France

Rhetorical Usage of Ambivalent Notions in the French Publishing Industry.

Independence and Autonomy

Los usos retóricos de nociones ambivalentes en el sector editorial. Independencia y autonomía

Sophie Noël

\section{(2) OpenEdition}

Journals

Édition électronique

URL : http://journals.openedition.org/bssg/339

DOI : $10.4000 /$ bssg.339

ISSN : 2490-9424

Éditeur

Presses universitaires de Vincennes

Référence électronique

Sophie Noël, «Indépendance et autonomie », Biens Symboliques / Symbolic Goods [En ligne], 4 | 2019, mis en ligne le 27 juin 2019, consulté le 04 mars 2021. URL : http://journals.openedition.org/bssg/339 ; DOI : https://doi.org/10.4000/bssg.339 


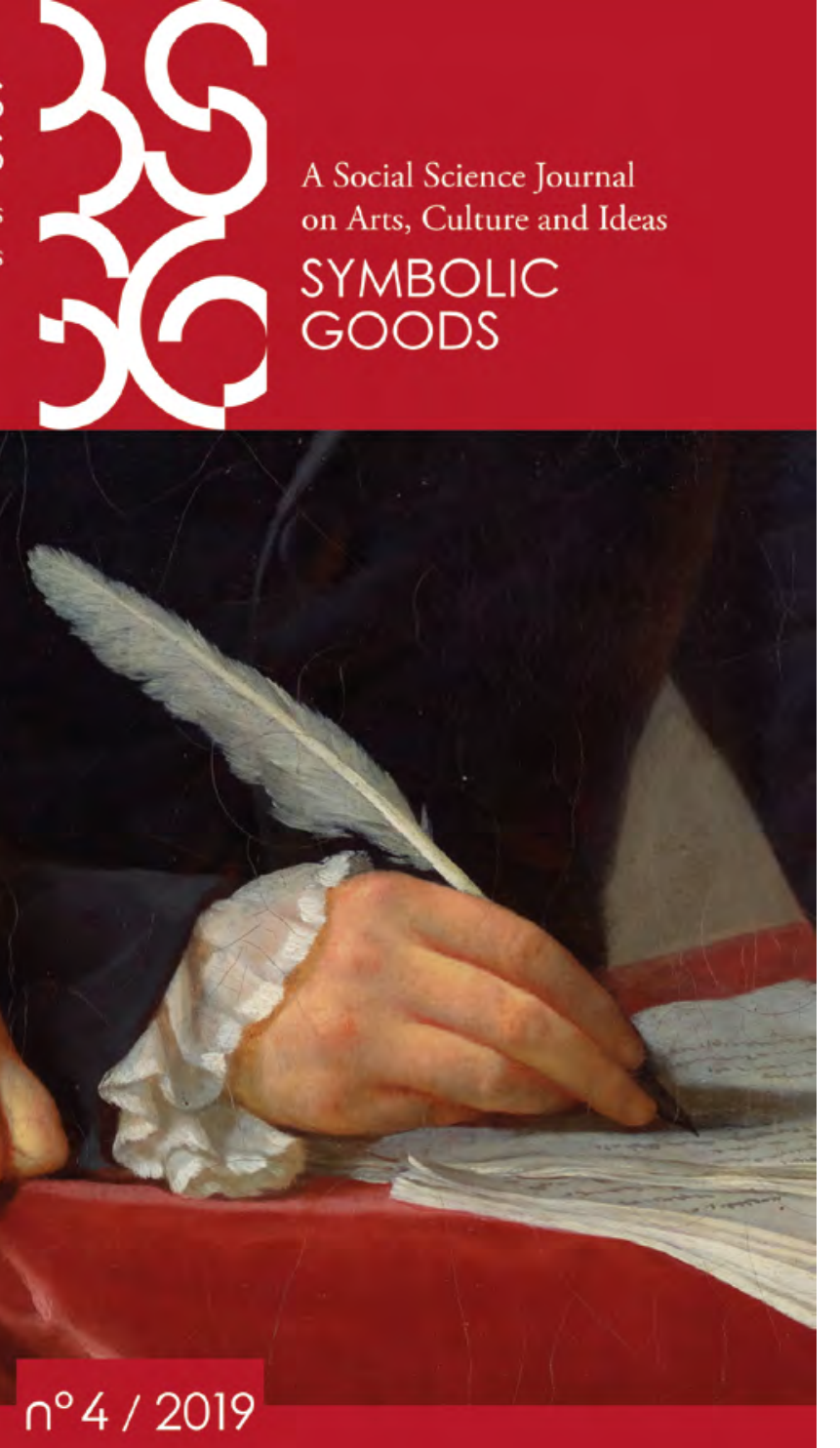

Autonomies des arts et de la culture Autonomies of Art and Culture 


\title{
Indépendance et autonomie Independence and Autonomy \\ Des usages rhétoriques de quelques Rhetorical Usage of Ambivalent Notions notions ambivalentes dans le secteur du in the French Publishing Industry \\ livre en France
}

\author{
Sophie Noël \\ traduction | translation \\ Katharine Throssell
}

\begin{abstract}
Introduction
La revendication d'indépendance a pris dans les espaces de production symbolique, et en particulier dans le secteur du livre, une importance croissante. Nombreuses sont les structures éditoriales ou les librairies se définissant comme « indépendantes ${ }^{1}$ » dans un contexte de rationalisation économique perçu comme une menace pour leur autonomie telle que la définit la sociologie de la culture. La confrontation entre ces deux notions proches, l'une (l'indépendance) évoquant les catégories indigènes, l'autre (l'autonomie) renvoyant à l'univers savant, semble de ce fait particulièrement intéressante à explorer. Selon Pierre Bourdieu (1992 : 107), l'autonomie est la revendication par un champ du droit de définir lui-même les principes de sa légitimité, ou encore l'affirmation par un univers social de son indépendance à l'égard
\end{abstract}

1. Nous avons fait le choix de mettre des guillemets aux termes « indépendance » et « indépendant » pour indiquer qu'il s'agit de catégories indigènes mobilisées par les acteurs pour s'autodéfinir. Par souci de lisibilité, ces termes apparaîtront sans guillemets dans la suite de l'article, sauf en cas de besoin d'accentuation particulier.

\section{Introduction}

Claims of independence are increasingly common in the fields of symbolic production, and in particular in the publishing industry. Many publishing houses and bookshops describe themselves as "independent" 1 in a context of economic rationalization that they see as a threat to their autonomy, such as it is defined by the sociology of culture. It is particularly interesting to contrast these two similar notions-one (independence) evoking "indigenous" categories used by actors in the field, the other (autonomy) referring to the intellectual sphere. According to Pierre Bourdieu (1996: 61 ), autonomy refers to a given field claiming the right to define the principles of its own legitimacy for itself, or to a social sphere affirming its independence from external (political and economic) powers. In the sociology of culture, the notion of autonomy is more

1. We have chosen to use quotation marks around the terms "inde-pendence" and "independent" to show that these are indigenous terms that the actors use to define themselves. Out of a concern for readability, however, these terms are used without quotation marks for the remainder of the article, except to draw particular attention to them in certain instances. 
des puissances externes, politiques et économiques. Si la notion d'autonomie est plus souvent mobilisée en sociologie de la culture pour caractériser la production des intellectuels et des artistes que l'activité des intermédiaires qui publicisent leur production, l'importance croissante de ces derniers dans les champs de production culturelle (Jeanpierre \& Roueff 2014) en fait un terrain d'observation privilégié pour saisir les reconfigurations des secteurs de l'économie des biens symboliques (Duval \& Garcia 2012).

Cet article propose de contribuer à la réflexion sur la notion d'autonomie en s'interrogeant sur les usages de l'indépendance, devenue omniprésente dans les secteurs culturels (Hesmondhalgh 1999, Hibbett 2005), et d'analyser les liens entre les deux termes et les réalités auxquelles ils renvoient. Ce faisant, l'objectif est d'éclairer les enjeux liés à la mobilisation de la thématique de l'indépendance par deux catégories centrales d'acteurs du monde du livre : les éditeurs et les libraires. On s'appuiera pour cela sur une enquête (voir encadré) auprès de structures indépendantes au sens juridique du terme, c'est-à-dire maîtrisant leur capital ${ }^{2}$, dans le secteur de l'édition et de la librairie généralistes, qui présentent des problématiques communes tout en occupant des positions distinctes dans la chaîne du livre ${ }^{3}$.

2. L'indépendance est définie de manière minimale dans le secteur de l'édition comme de la librairie par le fait que le capital de l'entreprise appartient en majorité à une seule entité juridique ou personne physique. Les librairies indépendantes rassemblent ainsi près de 3000 points de vente très hétérogènes dont la caractéristique commune est de ne pas appartenir à une enseigne ou à une chaîne (Rouet 2007 : 211). Sur ce point, voir infra.

3. Les éditeurs et les libraires présentent de fortes analogies quant à leur rapport à l'indépendance. Bien que les libraires soient plus proches du monde du commerce que les éditeurs, et souffrent de ce fait d'un déficit de légitimité (Leblanc 1998), leur prestige s'est accentué ces dernières décennies et l'on peut parler d'homologie de position entre éditeurs et libraires indépendants. often used to describe the production of intellectuals and artists than that of the intermediaries who publish or publicize their creations. However, the growing importance of these intermediaries in the field of cultural production (Jeanpierre \& Roueff 2014) makes this a prime site for the observation and understanding of the reconfigurations of the different sectors of the economy of symbolic goods (Duval \& Garcia 2012).

This article aims to contribute to reflections on the notion of autonomy by questioning the uses of the term independence, which has become omnipresent in cultural sectors (Hesmondhalgh 1999; Hibbett 2005), and analyzing the links between the two notions and the realities to which they refer. In so doing, the goal is to shed light on the issues surrounding the mobilization of the theme of independence by two central categories of actor in the publishing industry: publishers and booksellers. In order to achieve this, we will draw on a study (see the presentation of the methodology below) conducted with structures that are legally independent, i.e., those who control their capital, ${ }^{2}$ in the sector of generalist publishing and bookshops. These actors face similar problems while occupying different positions in the book chain. ${ }^{3}$

2. Independence is defined in minimal terms in the publishing sector and in the bookshop industry, as the fact that the majority of a business's capital belongs to a single individual or legal entity. Independent bookshops in France thus represent 3,000 very heterogenous establishments; their primary shared characteristic is that they do not belong to a brand or a chain (Rouet 2007 : 211). On this point, see below.

3. Publishers and booksellers are quite similar in their attitude towards independence. Although booksellers are closer to the business world than publishers are and suffer from a lack of legitimacy as a result (Leblanc 1998), their status has increased in recent decades and we can now talk about an equivalence of positions between publishers and independent booksellers. 
Notre hypothèse est que la mise en avant de l'indépendance par des acteurs très divers - que ce soit par la taille ou l'envergure économique-répond à une perte d'autonomie au sens sociologique du terme, tout en leur fournissant une arme efficace pour la défense de positions menacées dans un secteur où la croyance dans le caractère spécifique du livre demeure forte. Alors que les contraintes économiques et la concurrence entre acteurs se font plus pressantes, l'indépendance devient une ressource symbolique et un enjeu dans la lutte pour la définition légitime de l'éditeur " de création » comme du libraire « de qualité » - nous reviendrons sur ces termes - et pour la reconnaissance, tant externe qu'interne, dont dépend en partie l'octroi de subventions publiques.

Pour autant, l'indépendance est un terme flou, à la définition non stabilisée, qui ne permet pas de clarifier les positions de ceux qui s'en revendiquent dans un espace social donné ${ }^{4}$. La grande plasticité du terme, tant sur le plan historique que géographique et sectoriel, pose par conséquent un certain nombre de problèmes, tout en présentant l'avantage de pouvoir agréger des acteurs aux propriétés et aux intérêts très divers (Habrand 2017). Revenir sur la genèse des usages rhétoriques ${ }^{5}$ de la notion d'indépendance dans le secteur du livre permettra dans un premier temps de clarifier ces ambiguïtés, avant de tenter de démêler les principales dimensions d'une catégorie polysémique. Nous verrons enfin comment l'indépendance est mobilisée en tant que ressource efficace dans différents espaces sociaux et auprès de différentes instances, avec quels enjeux et limites.

4. Pour une généalogie des significations et usages successifs du terme « indépendance » et de l'adjectif qui s'y rattache, voir Tanguy Habrand (2016).

5. Nous entendons « rhétorique » au sens de mobilisation d'un discours à visée persuasive.
Our hypothesis is that the emphasis on independence by actors that are very different from each other-whether in terms of size or economic activity-is due to a loss of autonomy in the sociological sense of the term. This notion of independence provides them with a weapon with which to protect their vulnerable positions in a sector where belief in the singular nature of book production remains strong. In a context in which economic constraints and competition between actors are becoming increasingly urgent, independence operates as a symbolic resource and has become a key issue in the struggle for the legitimate definition of "originating" publishers and "quality" bookshops. We will discuss these terms further below. Independence has also become important for gaining the recognition, both external and internal, that partly conditions the attribution of public subsidies.

Yet independence is a vague term. Definitions often lack precision and do not allow us to clarify the positions of those who use the term in a given social space. ${ }^{4}$ The elasticity of the term, in historical, geographical, and sectorial terms, raises a certain number of problems while also presenting the benefit of being able to bring together actors with various characteristics and interests (Habrand 2017). Revisiting the origins of the rhetorical uses ${ }^{5}$ of the notion of independence in the publishing sector will allow us to begin by clarifying these ambiguities before trying to disentangle the main elements of this polysemic category. We will then see how independence is mobilized as an effective resource in different social spaces and contexts, and what issues and limitations it encounters.

4. For a genealogy of the successive meanings and usages of the term "independence" and its associated adjective, see Habrand (2016).

5. Rhetoric is used here in the sense of the mobilization of an intentionally persuasive discourse. 


\section{Méthodologie}

Ce travail est issu d'une recherche menée auprès des éditeurs indépendants de critique sociale en France (Noël 2012a) complétée par une analyse documentaire réalisée entre 2015 et 2017 portant sur l'édition généraliste (dépouillement de la presse professionnelle, publications spécialisées, livres blancs et rapports ; analyse des catalogues et pages de présentation sur Internet). II s'appuie également sur une enquête en cours auprès des librairies indépendantes françaises (Noël 2018) : 22 entretiens semi-directifs ont été réalisés avec des responsables de librairies créées ces 20 dernières années à Paris et en régions, ainsi qu'avec des éditeurs et des représentants syndicaux et professionnels.

\section{De l'usage d'un concept flou : genèse de la rhétorique de l'indépendance dans le secteur du livre}

\subsection{Une prise de conscience tardive}

II faut d'abord rappeler le contexte général dans lequel s'inscrit la revendication d'indépendance au sein d'un secteur qui a connu de profondes transformations ces 30 dernières années (Mollier 2015a). Le mouvement de concentration capitalistique s'est fortement accéléré et internationalisé depuis les années 1980, avec pour conséquence un poids croissant des grandes structures à tous les niveaux de la chaîne du livre, le déclin des maisons familiales et une multiplication des petites entités ou franges de l'oligopole ${ }^{6}$. L'augmentation du volume de production (81 263 titres

6. Cette expression fait référence à la structure de marché, typique des industries culturelles, où un nombre réduit de grosses entreprises formant

\section{Methodology}

This research draws on a study conducted with independent publishers of social critique in France (Noël 2012a) and on analysis of documents relating to generalist publishing (professional literature, specialized publications, white papers and reports, analysis of catalogues and online presentation pages). It is also based on an ongoing study with independent bookshops in France (Noël 2018). Twenty-two semi-directive interviews were conducted with managers of bookshops set up in the last twenty years in Paris and other regions in France. Interviews were also conducted with publishers, professional representatives, and unions.

\section{The Use of a Vague Concept: Origins of the Rhetoric of Independence in the Publishing Sector}

\subsection{A Belated Awakening}

It is important to remember the general context in which claims of independence occur, in a sector that has gone through significant transformations over the past thirty years (Mollier 2015a). Since the 1980s, the movement towards the concentration of capital has increased rapidly and become more international, leading to a larger proportion of major players at all levels of the book production chain, the decline of family-run publishing houses, and an increase in the number of small entities on the fringes of the oligopoly. ${ }^{6}$ The rise in the volume of production $(81,263$ books were

6. This expression refers to the structure of the market, typical of culture industries, in which a small number of large companies set up an oligopoly 
ont été publiés en 2017 en France, tous secteurs confondus ${ }^{7}$ ), le poids croissant des best-sellers, la baisse des tirages moyens et l'accélération des rotations en librairie ont concouru à la marginalisation des acteurs les plus fragiles, au profit des structures disposant d'un accès privilégié au marché du fait de leur maîtrise de la distribution. Les dix premières entreprises d'édition assurent ainsi $88,9 \%$ de l'activité éditoriale en 2016 , tandis que le nombre de maisons d'édition indépendantes sur le plan capitalistique est passé de 144 à 110 en l'espace de deux ans ${ }^{8}$

Les éléments constitutifs du métier d'éditeur au pôle de production restreinte $^{9}$ - le temps long de la découverte des auteurs, la péréquation entre les titres, autant d'éléments associés à l'autonomie - ont été mis à mal par ce faisceau d'évolutions. Comme l'évoquait Pierre Bourdieu (1992 : 554), la division en deux marchés, caractéristique des champs de production culturelle depuis le milieu du XIX ${ }^{\mathrm{e}}$ siècle, semble menacée de disparition du fait de l'interpénétration de plus en plus grande entre le monde de l'art et le monde de l'argent. Un constat qu'il poursuivra dans son article consacré au champ éditorial, où il souligne que « de façon générale, la concentration s'accompagne d'une réduction du nombre et de l'autonomie littéraire des lieux de décision », favorisant la diffusion d'une « sorte d'universel commercial » (Bourdieu 1999 : 22). C'est

un oligopole contrôle une vaste part du marché, le reste étant représenté par un grand nombre de petites entreprises (Stigler 1968).

7. La production a pratiquement triplé entre 1970 et 2007. Source : BnF/ Département du dépôt légal.

8. Fabrice Piault, « Les 200 premiers éditeurs français », Livres Hebdo, n 1179 , 22 juin 2018

9. Pierre Bourdieu (1992) définit le pôle de production restreinte comme étant constitué par les acteurs culturels qui développent une production destinée à un public restreint, de cycle lent et définie par une logique de l'offre, auquel il oppose le pôle de grande production, aux caractéristiques opposées. published in 2017 in France, all sectors combined ${ }^{7}$ ), the increasing importance of bestsellers, a drop in the average size of print runs, and the acceleration of turnover in bookshops have all led to the marginalization of more fragile actors to the benefit of structures that have a privileged access to the market because they control distribution. In France, the ten largest publishing businesses were responsible for $88.9 \%$ of publishing in 2016 , while the number of independent publishing houses (in terms of capital) went from 144 to 110 in two years. ${ }^{8}$

The key elements that make up the publisher's role in the field of limited production ${ }^{9}$-the time spent discovering authors and balancing mainstream and more niche texts, which are elements associated with autonomy-have suffered from this convergence of evolutions. As Pierre Bourdieu argued (1996: 345) the division of the market into two, characteristic of the field of cultural production since the mid-nineteenth century, seems at risk of disappearing due to the increasing interconnectedness between the worlds of art and money. He pursued his observation in a later article dedicated to publishing, where he argued that "acquisition and integration generally result in a reduction of the number and literary autonomy of decision-making entities," which encourages a "commercial universal" (2008: 145-

controlling a vast sector of the market, with the rest represented by a large number of much smaller companies (Stigler 1968).

7. Production practically tripled between 1970 and 2007. Source: BnF/ Département du Dépôt légal.

8. Fabrice Piault (2018). "Les 200 premiers éditeurs français." Livres Hebdo, 1179, 22 June.

9. Pierre Bourdieu (1992) defines the field of restricted production as being made up of cultural actors that develop production targeted at a restricted public, with a long production cycle, and defined by a logic of supply, which he compares with the field of large-scale or mass production, which has the opposite characteristics. 
dans ce contexte que prend place la multiplication des appels à la " résistance » au sein de la chaîne du livre et à un retour aux sources (souvent mythifiées) de l'édition, c'est-à-dire à des valeurs et à des principes d'organisation liés à l'histoire du champ artistique et intellectuel dans sa phase la plus autonome : affirmation d'une logique de création, diversité de la production, non soumission aux sirènes du succès commercial. Cette présentation du salon L'Autre livre ${ }^{10}$ en fournit une illustration typique :

Pendant que nous nous efforçons avec peu de moyens d'être des passeurs d'imaginaire, d'idées, de mots susceptibles de découverte, de connaissance, de poésie, d'indignation... d'autres - des financiers - ont bien compris que le livre, avec ce qu'il représente d'émotions, peut avoir une valeur marchande avec laquelle il est possible de faire du profit ${ }^{11}$.

Cette mise en avant de l'indépendance s'observe sur l'ensemble des marchés de biens symboliques et en de nombreux points du globe. Si l'édition a connu une prise de conscience plus tardive de ce phénomène que d'autres secteurs comme le cinéma ${ }^{12}$ ou la musique enregistrée (avec la dénomination « indie » ou « indé » à partir des années 1970), cette dernière n'en a été que plus brutale du fait de la charge symbolique forte attachée aux livres en tant que vecteurs de culture et de savoir. Un détour par le passé permet de mieux comprendre comment, en France, le concept d'indépendance

10. Créé en 2003 , ce salon rassemble une cinquantaine de petits éditeurs indépendants sur le plan capitalistique.

11. Gérard Cherbonnier, "L'édition indépendante interdite ou menacée ? ", 9 novembre 2012. [En ligne] [consulté le 24 juin 2018].

12. Le secteur du cinéma a été confronté dès l'après-Première Guerre mondiale à la concurrence des majors états-uniennes, l'État intervenant très tôt pour défendre la production nationale (Duval 2016).
146). In this context, there has been a growing number of calls for "resistance" within the book chain and a return to the (often mythical) sources of publishing, in other words the organizing values and principles linked to the history of an artistic and intellectual field in its most autonomous phase. These involve the affirmation of a creative logic, a diversity in production that is not subject to the siren calls of commercial success. This presentation made at the alternative book fair L'Autre livre ${ }^{10}$ is a typical illustration of this:

While we try, with limited means, to be vectors of imagination, ideas, or words that lead to discoveries, knowledge, poetry, indignation [...] others-investors-have understood that books, with all that they represent in terms of emotion, can have a market value with which it is possible to make a profit. ${ }^{11}$

This emphasis on independence can be seen across all markets for symbolic goods in numerous places around the world. Although publishing only became aware of this phenomenon somewhat late in the day-compared with other sectors such as cinema ${ }^{12}$ or music (where the term "indie" was used from the 1970s) - it was all the more brutal because of the symbolic weight associated with books as vectors of culture and knowledge. A look at the history of the situation will allow us to understand how in France the concept

10. Established in 2003, this book fair brings together around fifty small, independent (in terms of capital) publishers.

11. Gérard Cherbonnier (2012). "L'édition indépendante interdite ou menacée?". November 9. [Online] [accessed on 24 June 2018].

12. The film industry was confronted with competition from major American studios after the First World War and the state intervened early on to protect national production in this area (Duval 2016). 
s'est progressivement imposé dans un secteur longtemps dominé par un capitalisme de type familial.

\subsection{Une émergence progressive}

Qu'il s'agisse du contrôle du pouvoir politique et religieux par le biais de la censure ou des contraintes économiques et financières, le monde de l'écrit a toujours dû se définir par rapport à de fortes ingérences externes (Jouhaud 2000) s'exerçant à tous les niveaux de la chaîne allant de l'auteur au libraire. C'est dans la seconde moitié du XIX siècle, avec le processus d'autonomisation des champs de production culturelle (Bourdieu 1992) que se cristallise le nomos spécifique irriguant aujourd'hui les dénonciations de "perte d'indépendance ». L'affaire Dreyfus joue un rôle fondateur avec l'affirmation de l'indépendance des intellectuel-le·s vis-à-vis des pouvoirs temporels (Charle 1990) et le terme est repris dans l'entre-deux-guerres, des groupes d'intellectuel-le-s se mobilisant pour préserver la maîtrise de leurs écrits autour du projet des Presses universitaires de France $^{13}$ (Tesnière 2001). Le souci de l'indépendance économique des structures de diffusion comme garantie de l'indépendance des contenus produits se pose également pour financer les grands projets encyclopédiques du XIXe siècle dans une perspective d'émancipation des savoirs, ou encore, dans les années 1930, dans les tentatives de contrer "les grands trusts " (Douyère 2008). L'indépendance des intellectuel·le·s et des artistes est perçue comme inséparable de celle des structures (éditeurs,

galeristes d'art) permettant de publiciser leurs œuvres.

13. Les Presses universitaires de France (PUF) ont été créées en 1921 par un collège de professeurs sous forme de coopérative pour publier des ouvrages et revues scientifiques en sciences humaines. of independence has progressively come to dominate in a sector that was long controlled by family-run businesses.

\subsection{A Gradual Emergence}

Whether in terms of the control of political and religious power through censorship, or economic and financial constraints, the world of the written word has always had to define itself in relation to the external interferences (Jouhaud 2000) that operate at all levels of the book chain between the author and the bookseller. It was in the second half of the nineteenth century, as the field of cultural production (Bourdieu 1996) became progressively more autonomous, that the specific nomos that would feed the complaints of "loss of independence" began to take form. The Dreyfus affair played an important role in this, with intellectuals affirming their independence in opposition to temporal authorities (Charle 1990). The term was later taken up during the inter-war period, as groups of intellectuals mobilized to maintain control over their writings through the Presses Universitaires de France ${ }^{13}$ project (Tesnière 2001). The problem of the economic independence of distributors as a guarantee of the independence of the content produced also applies to the funding of the major encyclopaedic projects of the nineteenth century, from the perspective of the freedom of knowledge, as well as attempts in the 1930s to go against major companies (Douyère 2008). The independence of intellectuals and artists was seen as inseparable from that of the structures that allow them to publish and publicize their works (publishers, art galleries).

13. The Presses Universitaires de France (PUF) were created in 1921 by a group of professors, as a cooperative to publish scientific books and journals in social sciences. 
Cette problématique prend des formes renouvelées dans l'aprèsguerre. Dans le contexte de forte politisation du champ intellectue lié à la guerre froide, puis à la guerre d'Algérie et à la décolonisation, la question de l'engagement prend une place prééminente, mêlant étroitement considérations intellectuelles et politiques. L'éditeur « engagé » ou « protagoniste » (Hage 2016) est la figure marquante de la période, notamment autour des éditions de Minuit (Simonin 1994) et de François Maspero ${ }^{14}$, avant qu'un nouveau cycle de concentration économique ne replace au centre les notions d'indépendance capitalistique et de pluralisme dans les années 1980. Le glissement s'opère à nouveau d'une définition à dominante politique de l'indépendance - sous la forme de l'engagement - à une définition à dominante économique, même si les deux sont évidemment liées, comme l'illustre bien l'expression « censure de marché » (Schiffrin 1999)

L'inscription durable de la thématique de l'indépendance date cependant des années 1990, avec la prise de conscience de la place dominante des groupes Hachette et Vivendi dans le paysage éditorial français, qui culminera au moment de l'absorption partielle du second par le premier en $2004^{15}$. En 1993, Jean-Marie Bouvaist dénonce dans son ouvrage Crise et mutations dans l'édition française la logique prédatrice des grands groupes et, en 1999, L'Édition sans éditeurs de l'éditeur états-unien André Schiffrin devient le symbole de la résistance aux dérives du capitalisme d'édition.

14. Créées clandestinement sous l'Occupation, les éditions de Minuit ont publié dans les années 1950 plusieurs ouvrages en faveur de l'indépendance de l'Algérie. François Maspero est quant à lui le fondateur des éditions éponymes en 1959, qui ont joué un rôle central dans la diffusion de textes engagés à gauche, notamment anticoloniaux, dans les années 1960 et 1970.

15. Hachette Livre réalise $39 \%$ du chiffre d'affaires total de l'édition, suivi par Editis (13\%). Source : Fabrice Piault, « Les 200 premiers éditeurs français », op. cit.
This issue took on new forms after the war. In a context in which the intellectual field was heavily politicized due to the Cold War, and then the war in Algeria and decolonization, the question of engagement became central, closely combining intellectual and political considerations. The "politically engaged" or protagoniste (instigator) publisher (Hage 2016), was the striking figure of the period, particularly around the Éditions de Minuit (Simonin 1994) and François Maspero's publishing house, ${ }^{14}$ before a new cycle of economic centralism brought the notions of financial independence and pluralism to the fore in the 1980s. There was once again a slippage from a primarily political definition of independence-as a form of engagement-to a primarily economic definition. The two notions are clearly linked, however, as we can see in the expression "market censorship" (Schiffrin 1999).

The lasting inscription of independence as a theme can be traced back to the 1990s, however, with the rising awareness of the dominance of publishing groups such as Hachette and Vivendi in France (which would culminate in the partial absorption of the latter by the former in 2004). ${ }^{15}$ In 1993, Jean-Marie Bouvaist denounced the predatory approach of the major publishing groups in his article "Crise et mutations dans l'édition française." In 1999, the US publisher André Schiffrin's L'Édition sans éditeurs became the symbol of resistance against the excesses of capitalism in the publishing industry.

14. Created secretly during the occupation of France, the Éditions de Minuit then published several books defending Algerian independence in the 1950s. As for Francois Maspero, he was the founder of an eponymous publishing house in 1959, which played a central role in distributing left-wing, and particularly anticolonial, texts in the 1960s and 1970s.

15. In 2017, Hachette Livre accounted for $39 \%$ of the total publishing revenue in France, followed by Editis (13\%). Source: Fabrice Piault (2018). "Les 200 premiers éditeurs français." Livres Hebdo, 1179, 22 June. 


\section{André Schiffrin}

\section{L'édition}

\section{sans éditeurs}

Fig. 1. Couverture du livre d'André Schiffrin, L'Édition sans éditeurs Paris, La fabrique. Source : La fabrique éditions.
La fabrique

Editions
Fig. 1. André Schiffrin book cover

L'Édition sans éditeurs

André Schiffrin (1999). L'Édition sans éditeurs.

Paris, La fabrique.

Source: La fabrique éditions. 
Cet ouvrage, qui exporte hors des États-Unis la thématique de la résistance des acteurs indépendants face aux grands groupes, a fortement contribué à internationaliser les luttes contre des acteurs dominants eux-mêmes globalisés. Des associations comme l'Alliance internationale des éditeurs indépendants, créée en 2002 et fédérant près de 80 éditeurs issus de cinq aires linguistiques, ont également joué un rôle dans la diffusion et la circulation de ce concept (Lehembre 2017) en le liant à la problématique de la diversité culturelle et de la bibliodiversité. Des assises, des salons professionnels, des collectifs, des débats sont régulièrement organisés depuis les années 2000 , tandis qu'un corpus de littérature émanant de professionnel.le·s et d'analystes se développe sur ce sujet, contribuant à la formalisation de l'idée d'indépendance. II serait impossible d'énumérer ici l'ensemble des tribunes, livres blancs, témoignages et billets d'humeur publiés dans la presse ou sur Internet sur le sujet, qui ont accompagné l'émergence de la catégorie d'acteur indépendant dans le secteur du livre et l'inscription de ce référent identitaire dans l'espace public. Pour autant, et contrairement à d'autres secteurs culturels, la catégorie demeure peu mobilisée par l'État (voir infra) qui n'opère pas de distinguo entre les éditeurs indépendants et les acteurs dominants du marché. Les liens anciens avec Hachette (Mollier 2015b) de même que le besoin de favoriser des " champions nationaux " capables de rivaliser avec les conglomérats transnationaux du secteur expliquant sans doute cela.

$\mathrm{Au} \mathrm{xx}^{\mathrm{e}}$ siècle ${ }^{16}$, la catégorie de la librairie indépendante s'est progressivement substituée à celle de la librairie traditionnelle, laquelle renvoyait à une dimension plus commerciale que culturelle (Ozanne 2008), tout en présentant le même caractère

16. Retracer l'émergence de la librairie indépendante nécessiterait un retour historique trop important pour les limites de cet article. Nous renvoyons à l'ouvrage de Frédérique Leblanc \& Patricia Sorel (2008)
This book exported the theme of independent actors' resistance against major corporations outside of the United States. It made an important contribution to the globalization of struggles against dominant actors, which are themselves globalized. Associations such as the International Alliance of Independent Publisherscreated in 2002 and federating more than eighty publishers in five linguistic areas-also played a role in spreading and circulating the concept (Lehembre 2017) by connecting it to the problem of bibliodiversity (cultural diversity applied to the world of books). Since the early 2000 s, conferences, professional fairs, collectives, and debates have been organized regularly on the subject, and a literary corpus emanating from professionals and analysts is being developed, contributing to the formalization of the idea of independence. It would be impossible to list here the vast number of articles, white papers, accounts, and opinion pieces published in the media or on the internet that have followed the emergence of the independent actor in the publishing sector and its becoming an identity reference in the public space. However, and unlike what happens in other cultural sectors, the state does not use this category (see below) nor distinguish between independent publishers and the major players in the market. Long-term connections with Hachette (Mollier 2015b) along with the need to encourage "national champions" capable of competing with international conglomerates in the sector goes some way to explaining this.

In the twentieth century, ${ }^{16}$ the category of independent booksellers gradually replaced that of traditional booksellers, which were more commercial than cultural (Ozanne 2008), although it still presented

16. Retracing the emergence of independent booksellers would require a historical perspective that is too demanding for the confines of this article. For more information on this, see the book edited by Frédérique Leblanc and Patricia Sorel (2008). 
d'imprécision ${ }^{17}$. L'appellation librairie indépendante ${ }^{18}$ rassemble en effet des acteurs fortement hétérogènes allant de très grosses structures, notamment régionales, comme Mollat à Bordeaux (3e librairie de France avec un chiffre d'affaires de près de 25 millions d'euros en $2017^{19}$ ), à de très petites librairies au chiffre d'affaires de quelques centaines de milliers d'euros. En dépit de ces grandes disparités de situation, les librairies indépendantes, rassemblées par le sentiment d'une identité menacée, se sont mobilisées depuis les années 1990 contre les Fnac et autres grandes surfaces spécialisées et, à partir des années 2000, contre la vente en ligne d'Amazon, dans un contexte d'effritement de leur part de marché ${ }^{20}$. Le Syndicat de la librairie française (SLF), qui rassemble près de 600 librairies, a ainsi choisi en 2017 de promouvoir l'identité « librairie indépendante » sans imposer de critères spécifiques afin que tous ses adhérent·e·s (de la chaîne de librairies Gibert Joseph à la petite librairie de quartier, en passant par la librairie d'éditeur) puissent se retrouver autour d'un certain nombre de valeurs diffuses (la qualité, le conseil, la diversité...)

résumant « une manière indépendante d'exercer le métier ». the same vagueness of vocabulary. ${ }^{17}$ The title of independent bookshop ${ }^{18}$ in fact brings together strongly heterogenous actors, ranging from very large structures-notably regional structures, such as Mollat in Bordeaux (the third biggest bookshop in France with a turnover of nearly $€ 25$ million in $2017^{19}$ )-to very small bookshops with limited profit. In spite of these disparities of situation, independent booksellers have come together around the feeling of a threatened identity. Since the 1990s they have protested against Fnac and other major retailers, and from the early 2000s they campaigned against Amazon's online sales in a context of dwindling market share ${ }^{20}$. The French booksellers union (SLF), which represents nearly 600 bookshops, thus chose to promote the identity of the "independent bookshop" in 2017, without laying out specific criteria, so that its members (from the chain Gibert Joseph to the neighbourhood bookshop, including publishers' bookshops) might come together around a certain number of major values (quality, advice, diversity, etc.) summarising "an independent way of practising this trade."
17. Sur les différents termes mobilisés pour caractériser les librairies (« traditionnelles », « vraies », « indépendantes »...), voir l'article de Luc Pinhas (2008)

18. Environ 3000 en France, les librairies indépendantes regroupent toutes les structures, quelle que soit leur taille, n'appartenant pas à une chaine ou à une grande surface de type Fnac, Espaces culturels Leclerc ou Cultura.

19. Clarisse Normand (2018). «Les 400 premières librairies françaises ». Livres Hebdo, $\mathrm{n}^{\circ} 1175,25$ mai.

20. Les librairies réalisent $18,5 \%$ de la vente de détail, contre $20 \%$ pour la vente en ligne. Source : Observatoire de l'économie du livre, 2018.
17. On the different terms used to describe bookshops ("traditional," "genuine," "independent," etc.) see the article of Luc Pinhas (1998).

18. There are roughly 3,000 independent bookshops in France, covering all kinds of structures, regardless of size, that do not belong to a chain or one of the major retailers such as Fnac, Espaces Culturels Leclerc, or Cultura.

19. Clarisse Normand (2018). "Les 400 premières librairies françaises ?". Livres Hebdo, 1175, 25 May.

20. Brick and mortar bookshops account for $18.5 \%$ of retail sales, online structures for 20\%. Source: Observatoire de l'économie du livre, 2018. 


\section{LA CHARTE DES LIBRAIRES}

\section{LA CONFIANCE}

NOUS SOMMES INDEPENDANTS ET CHOISISSONS LES LIVRES EN FONCTION DE LEUR QUALITÉ ET DE VOS ATTENTES.

\section{LE COEUR}

NOUS AIMONS LES LIVRES. NOUS LES LISONS, NOUS LES DÉFENDONS, NOUS VIVONS AVEC EUX. NOUS LES VENDONS AVEC PASSION.

\section{LA CONVIVIALITÉ}

NOUS VOUS ÉCOUTONS, TENONS COMPTE DE VOS LECTURES ENVIES ET CRITIQUES. NOUS ORGANISONS POUR VOUS DÉBATS, INVITATIONS .

\section{LE CONSEIL}

DU PLUS CONNU A LINATTENDU, NOUS COMPOSONS POUR VOUS

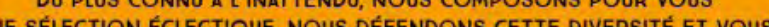
GUIDONS PARMI UNE IARGE VARIÉTE DE TITRES, DE RAYONS ET DE STYIES

\section{LA COMPÉTENCE}

NOUS SOMMES DISPONIBLES POUR VOUS ORIENTER, RECHERCHER ET COMMANDER N'IMPORTE QUEL LIVRE, LE METTRE A VOTRE DISPOSITION EN LIBRAIRIE OU VOUS

\section{LA CONNEXION}

NOUS VOUS ACCUEILIONS AUSSI EN LIGNE, SUR LES RÉSEAUX SOCIAUX OÙ VOUS POUVEZ CONTINUER DE DIALOGUER AVEC NOUS ET DE BÉNÉFICIER DE NOS SERVICES.

\section{LA CITOYENNETÉ}

NOUS AIMONS NOTRE QUARTIER ET NOTRE VILLE. NOUS Y VIVONS.

PAR NOTRE COMMERCE, NOS EMPLOIS, NOS IMPOTS ET NOS ANIMATIONS,

DONOMIQUE ET CULTURELLE.

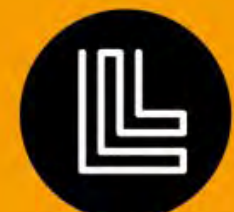

LIBRAIRIES

INDÉPENDANTES

\section{ÉLUES PAR LES LECTEURS}

LIBRAIRIESINDEPENDANTES.COM

Fig. 2. Poster of the Charte des Librairies Indépendantes

(Charter of Independent Bookshops)

Charter of Independent Bookshops, French booksellers union (SLF) campaign 2017.

Source: French booksellers union (SLF). 
Si la cristallisation de problématiques convergentes autour du concept d'indépendance peut donc être retracée dans le secteur du livre, il reste à comprendre ce à quoi ce dernier renvoie aujourd'hui dès lors qu'il est mis en avant par des acteurs présentant une grande hétérogénéité.

\section{L'indépendance, quelle indépendance? Trois dimensions pour un même concept}

L'indépendance est un terme polysémique qui se définit de manière relative et généralement négative (ne pas appartenir ou dépendre d'un autre que soi). II revêt de surcroît une dimension agonistique, l'indépendance étant le plus souvent conçue comme un état désirable à conquérir, voire à arracher, ou que l'on doit lutter pour maintenir. Employé dans des contextes différents, il renvoie à des enjeux de lutte distincts. Trois dimensions principales peuvent être dégagées afin de clarifier le propos.

\subsection{Une dimension juridique et capitalistique}

La première dimension est d'ordre juridique et capitalistique. Elle renvoie à l'opposition aux grands groupes, ainsi qu'à la prévalence des logiques mercantiles qui leur sont associées. Selon cette acception, est indépendante toute entreprise n'étant pas liée, juridiquement, à une structure externe, généralement plus importante. Cette définition, particulièrement opérante dans un contexte de concentration renforcée, s'alimente aux sources d'une opposition ancienne aux " gros » dans le secteur du commerce, comme l'a montré Laura Miller (2006) à propos des libraires étatsuniens. Derrière l'éditeur ou le libraire indépendant se profile toujours l'imaginaire du « petit » et de l'artisan, auquel est attaché un certain capital de sympathie dans l'imaginaire collectif.
Having seen these converging issues centre around the concept of independence within the publishing industry, we will now examine the problems and implications of the fact that this term is used by profoundly heterogenous actors.

\section{Independence, What Independence? Three Dimensions of a Single Concept.}

Independence is a polysemic term that is often defined in relative and generally negative terms (not belonging or depending on anything but oneself). It also takes on an agonistic aspect, often seen as something desirable, to be attained, to be seized, or that one must fight to maintain. Used in different contexts it evokes the stakes of various struggles. Three main dimensions can be identified in clarifying this.

\subsection{A Legal and Financial Dimension}

The first dimension relates to both legal status and ownership. It reflects the opposition to major corporations, and to the prevalence of the mercantile logics associated with them. According to this usage, any business that is not legally connected to an external structure, usually a larger one, is independent. This definition, particularly prevalent in a context of increased concentration of capital, draws on an established opposition to the "big" players in the commercial sector, as Laura Miller (2006) has demonstrated in relation to US bookshops. Behind the independent publisher or bookseller is always the idea of the "little guy," the artisan an image that carries a certain sympathy capital in the collective imaginary. 
L'association L'Autre livre (2005:20-21), créée au début des années 2000 pour défendre les petites structures d'édition, considère ainsi que l'édition indépendante englobe " tout éditeur n'appartenant pas à l'un des grands groupes de l'édition ».
The association L'Autre Livre (2005: 20-21) considers that independent publishing covers "all publishers who do not belong to major publishing groups." This minimal foundation reflects a selfevidence that is widely shared among the broader public and actors in the industry, even though the notion of "group" is clearly problematic, and the question of thresholds has never been resolved.

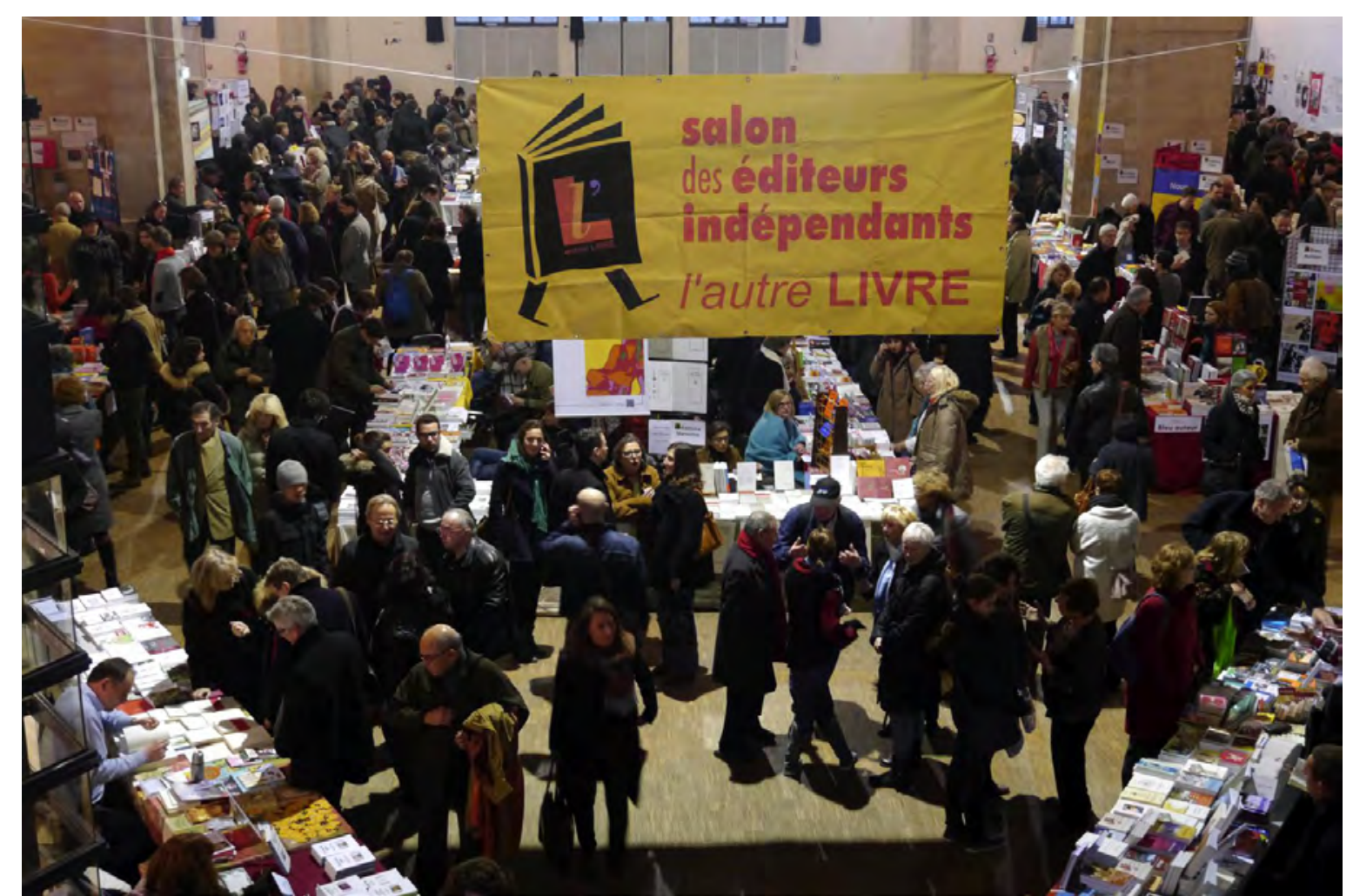

Fig. 3

livre, 2013, Paris. Source : L'Autre livre.
Salon L'Autre livre, an annual alternative book fair organised by small publishers, 2013, Paris. Source: L'Autre livre. 
Ce socle minimal renvoie à une forme d'évidence communément partagée par le grand public et les acteurs du secteur, même si la notion de groupe est évidemment problématique, et que la question des seuils n'est jamais aisée à trancher. L'exemple d'Actes Sud, parangon de l'édition indépendante depuis sa création à Arles en 1978, dont le capital est contrôlé par les fondateurs ${ }^{21}$, est à ce titre instructif. Aujourd'hui 9 e éditeur français ${ }^{22}$, la maison réalise un chiffre d'affaires de 80 millions d'euros et a pris des participations dans plusieurs autres structures - Jacqueline Chambon, Gaïa, Le Rouergue, Textuel, Payot-Rivages... - rattachées à ce qu'il faut bien appeler un groupe, même si ses fondateurs répugnent à utiliser le terme. Toute une série d'euphémismes à caractère organique (« un ensemble ») ou amical (« des maisons associées ») sont en effet mobilisés à l'usage des médias, permettant de préserver l'image valorisante de l'éditeur provincial atypique ${ }^{23}$. Faut-il considérer qu'au-delà d'un certain volume d'activité, une maison d'édition ne peut plus être qualifiée d'indépendante ? Et auquel cas, selon quels principes déterminer ce seuil ? La vision d'un marché éditorial polarisé entre des groupes de plus en plus importants et une myriade de petites structures plus ou moins professionnelles ne laisse que peu de place aux structures de taille intermédiaire.

À l'inverse, certains acteurs se font fort de rappeler la grande précarité des indépendants, tel Philippe Picquier, directeur de la maison éponyme spécialisée en littérature asiatique : " J'ai heureusement perdu une partie de mon indépendance, cela

21. La holding Actes Sud Participations est possédée à $95 \%$ par Françoise Nyssen et Jean-Paul Capitani.

22. Fabrice Piault, «Les 200 premiers éditeurs français », op. cit.

23. "Dans la maison, on bannit le terme "groupe", lui préférant "ensemble". Pas de "filiales" mais des "maisons associées" » (Anne-Laure Walter [2008] «Actes Sud. Ceci n'est pas un groupe » Livres Hebdo, n 732, 2 mai).
The example of Actes Sud is instructive, given that it has been a paragon of independent publishing (its capital is controlled by its founding members ${ }^{21}$ ) since its creation in Arles in 1978. Today it is the ninth largest French publisher ${ }^{22}$ with an annual turnover of $€ 80$ million. It has also invested in several other publishing structures-Jacqueline Chambon, Gaïa, Le Rouergue, Textuel, Payot-Rivages...-creating what has to be called a group, although the founding members reject the use of that term. A whole range of euphemisms, whether evoking natural groups ("an ensemble") or friendship and community ("associated publishers") have been employed in the media, thus preserving the high-status image of the atypical provincial publisher. ${ }^{23}$ Should we consider that beyond a certain volume of activity a publishing house can no longer be described as independent? In which case, what criteria should determine the threshold? The vision of the publishing market polarized between increasingly large groups and a myriad of more or less professional small structures leaves little room for mediumsized organizations.

Conversely, some go to great lengths to draw attention to the insecurity of independent actors. Philippe Picquier, for example, the head of the eponymous publishing house [specializing in Asian

21. Ninety-five per cent of the holding company Actes Sud Participations is owned by Françoise Nyssen and Jean-Paul Capitani.

22. Fabrice Piault (2018). "Les 200 premiers éditeurs français." Livres Hebdo, 1179, 22 June.

23. 'In publishing houses, the term 'group' is banned; 'ensemble' is used instead. There are no 'branches,"' but rather "associated publishing houses." (AnneLaure Walter [2008]. "Actes Sud. Ceci n'est pas un groupe." Livres Hebdo, 732, 2 May). 
m'a permis d'aller plus loin ${ }^{24}$." Michel Valensi, qui publie des ouvrages de sciences humaines et de littérature depuis 1985 au sein des Éditions de l'Éclat, témoigne de son côté des difficultés économiques récurrentes des structures fonctionnant sans appui

extérieur :

Je ne sais pas sij'édite librement, ni si je suis indépendant. Mais pour le moment, je me sens pieds et poings liés par une situation économique difficile, et assez peu libre de mes mouvements ${ }^{25}$

Pour les acteurs ayant « fait le choix » du rachat ou de l'absorption par une tierce structure, la perte de l'indépendance capitalistique est le prix à payer pour échapper à l'auto-exploitation et à une pratique amateur les condamnant aux marges du champ éditorial. Nombreux sont en effet les éditeurs ayant rejoint un groupe qui mettent en valeur une indépendance éditoriale favorisée par la protection de leur maison mère, cette dernière leur assurant un confort économique qui rend possible la création, selon la division classique entre principe créateur et principe gestionnaire (Chiapello 1998).

Christian Robin (2008) rappelle par ailleurs que l'indépendance est presque toujours relative : les liens de dépendance qu'une maison d'édition entretient avec son diffuseur-distributeur ${ }^{26}$ l'empêchent

24. Cité dans Catherine Andreucci, (2006). « Les indépendants veulent du concret ». Livres Hebdo, $n^{\circ} 666,17$ novembre. La structure de diffusiondistribution Harmonia Mundi a racheté $60 \%$ du capital de la maison suite à des difficultés financières.

25. Michel Valensi, introduction aux « Troisièmes rencontres départementales de l'édition indépendante », 17 septembre 2010, Marseille.

26. Le diffuseur assure la représentation commerciale de la production d'un éditeur en librairie, tandis que le distributeur prend en charge la livraison physique (et les retours) des ouvrages. La majorité des éditeurs sous-traitent cette literature], says, "Fortunately, I have lost part of my independence, and that has allowed me to go further. ${ }^{24 "}$ Michel Valensi, who has published works in humanities and literature since 1985 within Éditions de l'éclat, recounts the recurring economic difficulties of structures that operate without any external support:

I do not know if I publish freely, nor if I am independent. But for the moment, I feel like my hands and feet are tied by a difficult economic situation, and like I don't have much freedom of movement. ${ }^{25}$

For actors who have "made the choice" to be bought up or absorbed by an external structure, loss of legal independence is the price they pay to escape self-exploitation and amateur-type practices that leave them sidelined on the fringes of the publishing world. In fact, publishers who have been absorbed by a larger group often value a form of independence facilitated by the protection of a head office that provides them with the economic security to create freely. This follows the classical division between creative principles and management principles (Chiapello 1998).

Moreover, Christian Robin (2008) argues that independence is nearly always relative: the relationship of dependency that a publishing house has with its sales and distribution suppliers ${ }^{26}$

24. Quoted in Catherine Andreucci (2006). "Les indépendants veulent du concret." Livres Hebdo, 666, 17 November. The distributors Harmonia Mund bought up $60 \%$ of the publisher's capital following financial difficulties.

25. Michel Valensi, introduction to "Troisièmes rencontres départementales de l'édition indépendante," 17 September 2010, Marseille.

26. The sales representatives are responsible for the commercial representation of a publication in a bookshop, whereas the distributor is responsible for physical stockage and delivery (and returns) of books. Most publishers subcontract this work to one of the major actors in the field, connected to a 
de maîtriser sa politique commerciale (taux de remises, conditions de vente). La maison d'édition jeunesse l'École des loisirs ${ }^{27}$ serait ainsi une des rares à être "véritablement » indépendante puisqu'elle dispose de sa propre équipe de représentants en librairie. De même un libraire, surtout de petite taille, ne dispose en réalité que d'une faible marge de manœuvre puisqu'il n'a pas la maîtrise du prix des livres qu'il propose à la vente, ni des remises qui lui sont accordées par les diffuseurs ${ }^{28}$. II subit bien souvent des " offices sauvages ", c'est-à-dire des envois d'ouvrages non commandés, ou encore en exemplaires plus importants que ceux demandés, qu'il doit renvoyer à ses frais. Une libraire parisienne explique ainsi comment elle doit se défendre face aux pressions des fournisseurs :

Je reçois encore des offices sauvages de gros diffuseurs. Comme je n'ai pas de place pour stocker les livres, c'est des luttes infernales, de plus en plus dures. Alors je commande au minimum, à flux tendus ${ }^{29}$

\subsection{Une dimension artistique et intellectuelle}

À cette première acception de l'indépendance se superpose une dimension artistique et intellectuelle, qui se comprend en termes de maîtrise des contenus développés par rapport à la demande, et renvoie à la logique de l'art pour l'art et des avant-gardes. Cette

activité à l'un des gros acteurs du secteur, lié à un groupe éditorial : Hachette, Interforum (Editis), CDE-Sodis (Gallimard), ou encore Union Distribution.

27. Créée en 1965, l'École des loisirs est une maison d'édition jeunesse de référence en France.

28. La loi Lang sur le prix unique du livre accorde à l'éditeur le droit de fixer le prix de vente de ses livres. Les négociations avec les diffuseurs sont donc cruciales, et les petites librairies peinent généralement à obtenir de bonnes conditions commerciales.

29. Entretien, 3 avril 2015. leads to a loss of control over its commercial policy (conditions of sale, discount rates, etc.). The children's book publisher l'École des Ioisirs ${ }^{27}$ is, according to these criteria, one of the rare exceptions in being "genuinely" independent, because they have their own team of representatives in bookshops. Similarly, a bookshop, especially a small one, only has a small margin of manoeuvre, because they do not control the prices of the books nor the discounts that are applied by the sales team. ${ }^{28}$ They are often subject to unsolicited book deliveries, or a greater number of volumes than ordered, which must be returned to the publisher at the cost of the bookshop. One Parisian bookshop owner explains how she has to defend herself against the pressure of suppliers:

I still receive unsolicited items from the big distributors. It's a hellish battle because I don't have room to stock the books, it's harder and harder. So I order the minimum, on a just-in-time basis. ${ }^{29}$

\subsection{An Artistic and Intellectual Dimension}

This first definition of independence is associated with a second that is more artistic and intellectual, which can be understood in terms of a mastery of the content developed in relation to demand, and which reflects an avant-garde, art-for-art's-sake mentality.

publishing group: Hachette, Interforum (Editis), CDE-Sodis (Gallimard), or Union Distribution.

27. Established in 1965, the École des loisirs is a renowned publisher of children's literature in France.

28. The Lang law on fixed book prices gives the publisher the right to set the price for the books they publish. Negotiations with sales representatives are therefore crucial, and small bookshops generally struggle to obtain advantageous commercial conditions.

29. Interview, 3 April 2015 
acception est particulièrement prégnante dans d'autres secteurs des industries culturelles, notamment la musique rock, où l'indépendance des labels est historiquement associée à une production alternative, détachée des logiques et des formats du mainstream (Newman 2009). L'idée sous-jacente est que les indépendants, confondus dans ce cas strictement avec ce que les sociologues appellent le pôle de production restreinte, publient/valorisent des textes plus originaux, plus diversifiés que les acteurs répondant à une demande préexistante. C'est ce à quoi renvoie implicitement la définition de l'Alliance internationale des éditeurs indépendants qui développe pour ce faire la notion « d'éditeur de création »:

L'éditeur indépendant [...] est un éditeur de création. À travers ses choix éditoriaux souvent innovants, sa liberté d'expression, ses prises de risque éditoriales et financières, il participe au débat d'idées, à l'émancipation et au développement de l'esprit critique des lecteurs $[\ldots]^{30}$.

Un éditeur occupant une position économiquement fragile peut tenir à conserver la maîtrise de sa ligne éditoriale (choix des auteurs, des thématiques), comme un libraire peut vouloir contrôler l'assortiment des titres exposés. Dans les deux cas est affirmé le droit de définir soi-même les principes de sa légitimité, selon la définition savante de l'autonomie. Comme l'affirme la responsable d'une maison d'édition de littérature étrangère : « Être indépendant, c'est travailler dans une maison d'édition dont on maîtrise les orientations idéologiques et intellectuelles ${ }^{31}$. "

Pour les libraires, l'indépendance sur le plan intellectuel est souvent assimilée à la possibilité de maintenir en magasin des titres du

30. [En ligne] [consulté le 2 juillet 2018]

31. Entretien, 5 avril 2012.
This understanding is particularly visible in other sectors of cultural industries, such as rock music where the independence of music labels is historically associated with an alternative production, dissociated from the approaches and formats of mainstream music (Newman 2009). The underlying idea is that independent producers, synonymous in this case with what sociologists call the field of restricted production, publish and prioritize texts that are more original and more diversified than those chosen by actors who respond to a pre-existing demand. This is what the definition of the International Alliance of Independent Publishers implicitly refers to, through the notion of "originating publishers."

Independent publishers [...] are originating publishers: through their often innovative publishing choices, freedom of speech, publishing and financial risk-taking, they participate in discussions, distribution, and development of their readers' critical thinking. In this regard, they are key players in bibliodiversity. ${ }^{30}$

A publisher in an economically fragile position may want to retain control over their editorial line (choice of authors, themes, etc.), much as a bookseller may wish to control the range of books presented. In both cases they affirm the right to define the principles of their own legitimacy, according to the scholarly definition of autonomy. In the words of the manager of a press focusing on foreign literature: "Being independent means controlling the ideological and intellectual orientations of one's publishing house." 31

For booksellers, independence on an intellectual level is often associated with the ability to maintain backlist titles in stock-

30. [Online] [accessed on 2 July 2018]

31. Interview, 5 April 2012 
fonds - c'est-à-dire qui ne sont pas des nouveautés - ou encore de promouvoir la production d'éditeurs relativement confidentiels avec lesquels ils partagent un ethos commun. En se ménageant un petit espace de liberté en marge de ce qu'ils perçoivent comme la tyrannie de l'actualité et des best-sellers médiatisés, ils affirment leur rôle de prescripteur et non de simple vendeur. Comme le souligne un libraire de l'Est parisien

L'indépendance, tu la mesures vraiment le jour où le meilleur bouquin que tu as lu dans le mois, tu le mets en pile et tu le vends, alors qu'il n'a aucune actualité et n'a eu aucune presse. Quand tu n'es pas indépendant, tu n'as pas le droit de faire ça, de mettre à l'honneur des classiques ou un livre qui est sorti il y a trois ans ${ }^{32}$.

Pour autant, l'indépendance des structures ne s'identifie pas toujours à la qualité ou l'originalité des contenus, alors que ces critères d'évaluation tendent à prévaloir au pôle de production le plus autonome. Quantité de petites structures ont en effet une existence éphémère ou extrêmement marginale (Legendre \& Abensour 2007), et leur production n'a rien de remarquable. Si la notion indigène de l'indépendance et le concept sociologique de l'autonomie ne peuvent être tenus pour équivalents, c'est aussi qu'il arrive aux grandes maisons d'édition, qu'elles appartiennent à un groupe ou qu'elles aient elles-mêmes racheté certains de leurs concurrents, de publier les auteurs les plus reconnus par leurs pairs, comme l'illustre le catalogue de Gallimard en littérature étrangère (Sapiro \& Bokobza 2008). Le jeu des collections au sein d'une même maison d'édition, qui fait coexister des espaces d'autonomie

32. Entretien, 6 mai 2015. ie., those that are not new releases-or to promote privileged relationships with publishing houses that share a similar philosophy. By carving out a small space of freedom on the margins of what they consider to be the current tyranny of media-fed bestsellers, they affirm their role as prescribers rather than simply as sellers. One bookseller in the east of Paris puts it like this:

Independence, you really see it when the best book you've read in a month, you display it, and you sell it, without any media, or any publicity. When you're not independent, you're not allowed to do that, to put a spotlight on classics, or on a book which came out three years ago. ${ }^{32}$

And yet the independence of a press or a bookshop is not always associated with the quality or the originality of its production/ stock, whereas these criteria for evaluation tend to dominate at the pole of the most autonomous productions. Many small structures have an ephemeral or extremely marginal existence (Legendre \& Abensour 2007), and their production is by no means remarkable. If the actors' usage of independence and the sociological concept of autonomy cannot be considered strictly equivalent, this is because large publishing houses (whether they belong to a group or have absorbed their competitors) also publish authors who are widely recognized by their peers, as we can see in Gallimard's catalogue of foreign literature (Sapiro \& Bokobza 2008). The coexistence of different series within a given publishing house, which creates spaces of autonomy alongside spaces dedicated to

32. Interview, 6 May 2015. 
avec des espaces voués à une production plus commerciale - que l'on songe par exemple à la collection «Bouquins » chez Robert Laffont $^{33}$ - vient encore complexifier les choses.

On sait qu'il est souvent malaisé de tracer une ligne de séparation étanche entre critères intellectuels et commerciaux. Comme l'a montré Anne Simonin (2004) pour les éditions de Minuit, connues pour leur politique éditoriale sans compromis dans le domaine littéraire, même les choix les plus «purs " s'accompagnent de décisions plus commerciales, ne serait-ce que pour faire jouer la péréquation entre les titres indispensable au fonctionnement d'une activité aussi incertaine que l'édition. Percevoir le champ éditorial comme une mosaïque de sous-champs plus ou moins autonomes conjuguant logique économique et logique symbolique en fonction de leur position dans la distribution des ressources rares donne sans doute une image plus proche de la réalité qu'une opposition stricte entre champ de production restreinte et champ de grande production (Thompson 2005 : 30-36). De même, les libraires indépendants tendent à panacher leur assortiment entre les locomotives de la rentrée littéraire, aux ventes assurées, et leurs « coups de cœur » sur des titres plus confidentiels, tout en se réservant parfois la possibilité de ne pas mettre en valeur les auteurs qu'ils estiment peu.

\subsection{Une dimension politique}

La troisième dimension est d'ordre politique : l'indépendance se comprend alors dans le sens de la contestation de l'ordre dominant, de l'expression d'une pensée subversive. Elle s'incarne dans les formes d'édition alternative, underground, contestataire ou, depuis les années 1990, dans les petites maisons de

33. Cette collection abrite des ouvrages de référence en littérature au sein d'une maison d'édition, Robert Laffont, à l'identité plutôt commerciale. more commercial production-for example Robert Laffont's series "Bouquins" ${ }^{33}$ - further complicates things.

We know that it is often difficult to make a clear separation between intellectual and commercial criteria. As Anne Simonin (2004) has demonstrated for the case of Éditions de Minuit, well known for their uncompromising editorial line in the literary sphere, even the "purest" choices are associated with more commercial decisions, if only to leverage successful works against more specialist ones, fundamental to the functioning of an industry as uncertain as publishing. Considering the publishing field as a mosaic of subfields of varying autonomy that combine economic with symbolic logics depending on their position in the distribution of limited resources undoubtedly provides a more realistic image, rather than a strict opposition between a field of restricted production and one of largescale production (Thompson 2005: 30-36). Similarly, independent bookshops tend to balance their stock of books between darlings of the literary season, which are sure to sell, and their own, less well known, favourites. They are therefore able to retain the ability to not promote the authors for whom they have less consideration.

\subsection{A Political Dimension}

The third dimension is political: independence can be understood in the sense of challenging the dominant order, the expression of subversive thought. It is therefore incarnated in forms of alternative, underground, or protest publishing. Since the 1990s, small publishing houses that focus on social critique (Noël 2012a)

33. This series includes classic literary texts. The publishing house Robert Laffont has a relatively commercial image. 
critique sociale (Noël 2012a) qui renouent avec le tropisme de l'engagement déjà évoqué. Une des meilleures illustrations en est donnée par la structure éditoriale à but non lucratif créée en 1996 par Pierre Bourdieu, Raisons d'agir avec l'ambition de donner aux universitaires les moyens de mieux contrôler la diffusion de leurs travaux tout en traitant de questions de société et d'actualité destinées à un public élargi. Cette initiative éditoriale visait à reconquérir une certaine autonomie face aux forces économiques et aux relais médiatiques en promouvant des analyses allant à l'encontre de la pensée dominante, tout en se donnant les moyens d'une diffusion efficace grâce à la force commerciale des éditions du Seuil. Éclipsée depuis « l'âge d'or » des années 1960-1970, la dimension politique de l'indépendance est ainsi revenue en force au tournant des années 1990 dans plusieurs secteurs de l'édition comme la bande-dessinée ${ }^{34}$ ou la jeunesse, sans pour autant se substituer aux deux précédentes.

$\mathrm{Au}$ terme de ce rapide passage en revue des différentes significations de l'indépendance dans le secteur du livre, force est de constater que les critères mobilisés sont à la fois normatifs et flottants. La définition du terme indépendant est en effet devenu un enjeu de luttes (Boutet 2010), comme l'a illustré la polémique qui a précédé le rachat d'une partie du groupe Vivendi par Hachette en 2004. Des éditeurs de taille moyenne (à l'époque) comme Le Seuil, Gallimard et La Martinière ont opposé " l'édition indépendante " qu'ils étaient censés représenter aux grands groupes menaçant de déséquilibrer l'ensemble du marché par leur position hégémonique. Cette controverse a surtout montré à quel point l'usage du terme indépendant est devenu un enjeu définitoire, chacun "visant à imposer la définition des conditions d'appartenance les plus favorables à ses intérêts » (Mauger $2007: 5$ ). C'est une figure

34. Voir par exemple l'article de Benjamin Caraco (2017). have revived the idea of political and intellectual engagement mentioned above. One of the best examples of this is the non-profit publishing body Raisons d'agir created in 1996 by Pierre Bourdieu, which aimed to give academics and researchers the means to better control the dissemination of their work, while also dealing with social issues and current affairs directed at a broader public. This publishing initiative aimed to reclaim a certain autonomy in the face of economic and media forces, by promoting analysis that runs counter to the dominant perspective while still benefiting from efficient distribution channels thanks to the commercial power of Éditions du Seuil. The political dimension of independence, having waned after the "golden age" of the 1960s-1970s, thus returned in full force in the early 1990s in several publishing sectors, such as graphic novels ${ }^{34}$ and children's literature, although it remained complimentary to the two other dimensions discussed above.

From this rapid review of different meanings of independence in the publishing industry, we must conclude that the criteria employed are both vague and normative. The definition of the term independent has become a stake in various struggles (Boutet 2010), as we can see in the controversy that preceded the acquisition of part of the Vivendi group by Hachette in 2004. Medium-sized publishers (as they were then) such as Le Seuil, Gallimard, and La Martinière considered "independent publishing," which they saw themselves as representing, to be in opposition with major groups that threatened to unbalance the market with their hegemonic positions. This controversy above all demonstrated the extent to which the term independent has become an issue of definition, with each actor "aiming to impose the definition of the conditions of belonging that best suits their own interests" (Mauger 2007: 5). It has become a figure of distinction that allows one to situate oneself within a

34. See, for example, the article of Benjamin Caraco (2017) 
de distinction permettant de se situer au sein d'un espace nimbé de propriétés positives, voire vertueuses, tout à la fois principe de classement et de légitimation face au repoussoir du grand groupe et des pratiques qui lui sont associées, à l'heure où la dimension commerciale du métier se fait plus prégnante. La figure quelque peu héroïque du « petit éditeur indépendant » ou du « libraire indépendant de quartier », dont les médias sont friands, en fournit régulièrement l'illustration. Mais comment cette ressource est-elle mobilisée concrètement par les acteurs qui s'en revendiquent ? Et avec quelle efficacité ?

\section{Une ressource centrale dans la lutte pour la définition légitime au pôle de production restreinte}

On observe que l'indépendance est principalement mobilisée à trois niveaux dans le secteur du livre - vis-à-vis des pouvoirs publics, du grand public et des pairs - l'enjeu étant chaque fois

l'obtention de ressources matérielles et symboliques.

\subsection{L’État, interlocuteur privilégié}

La puissance publique joue depuis les années 1970 en France un rôle de recours face aux forces du marché (Dubois 1999), et ce phénomène n'a fait que s'accentuer depuis lors. Elle garantit le maintien d'une certaine diversité des productions, comme des acteurs, par le biais de dispositifs d'aides et de subventions aux maisons d'édition et aux librairies (le Centre national du livre [CNL], les directions régionales des affaires culturelles, l'Association pour le développement des space adorned with positive (even virtuous) characteristics, which are also principles of classification and legitimacy by opposition to the major publishing groups and the practices associated with them in a context where the commercial aspects of the business are increasingly significant. The somewhat heroic figures of the "smal independent publisher" or the "local independent bookshop," which the media adore, provide a regular illustration of this. But how is this resource used in concrete terms by the actors who claim it? And how effective is it really?

\section{A Central Resource in the Struggle for a Legitimate Definition Within the Field of Restricted Production}

We can see that independence is primarily mobilized at three levels in the publishing industry: directed at government authorities; the general public; and other industry actors. In each instance, it is the obtention of symbolic and material resources that is at stake.

\subsection{The State: Privileged Exchange Partner}

Since the 1970s, public authorities in France have acted as a buffer against market forces (Dubois 1999), and this phenomenon has only accelerated in recent years. The state guarantees the maintenance of a certain diversity in production and actors, through subsidies and assistance to both publishing houses and booksellers (the Centre national du livre [CNL], as well as regional funding for cultural affairs and Association pour le développement 
librairies de création [Adelc] ${ }^{35}$ ), mais aussi d'un cadre institutionnel et juridique dérogatoire qui permet de contrebalancer en partie les logiques marchandes avec la loi sur le prix unique et la TVA réduite sur le livre ${ }^{36}$. Ce rôle de l'État dans l'autonomisation de la filière du livre n'est pas sans rappeler le secteur du cinéma, où les aides publiques participent depuis les années 1950 à l'élaboration d'une définition officielle de la « qualité » et contribuent à l'indépendance de la « création » face au marché (Duval 2016 : 262).

L'ensemble de ces dispositifs permet à des projets perçus comme financièrement irréalisables en raison de l'étroitesse de leur marché « naturel » ou de leur ambition intellectuelle de voir le jour. Une jeune maison d'édition dénuée de ressources comme Les Prairies ordinaires a ainsi pu mener une politique éditoriale exigeante à base de traductions dans le domaine des sciences humaines au début des années 2000 en s'appuyant sur le Conseil régional d'Île-de-France, publiant en français un certain nombre d'auteurs anglophones majeurs (David Harvey, Mike Davis, Frederic Jameson). De tels éditeurs se trouvent néanmoins en concurrence avec des maisons plus importantes, qui mettent en avant la qualité de leur production. Ce sont d'ailleurs les éditeurs généralistes « dominants », tels Gallimard, Le Seuil ou Flammarion, qui concentrent la majorité des aides du CNL à destination des

35. Établissement public du ministère de la Culture, le Centre national du livre a pour mission de soutenir tous les acteurs de la chaîne du livre. L'Adelc a été créée en 1988 par quatre éditeurs (Gallimard, Minuit, Le Seuil, La Découverte) avec le soutien du ministère de la Culture, avec l'objectif d'apporter aux librairies aide technique et soutien financier.

36. La loi Lang a instauré en 1981 le prix unique du livre Ce prix est fixé par l'éditeur, et le vendeur, quel qu'il soit, ne peut proposer de réduction supérieure à $5 \%$. des librairies de creation [ADELC] ${ }^{35}$ ). It also does so through an institutional and legal framework of exemptions that allows them to offset commercial approaches with the law on the fixed price and reduced VAT on books. ${ }^{36}$ The state's role in the autonomization of the book trade is also reminiscent of the cinema industry, in which, since the 1950s, public funding has helped create an official definition of "quality" and contributed to the independence of "creation" in opposition to the market (Duval 2016: 262).

All of these programmes enable the production of projects perceived as financially unviable, due to the restricted nature of their "natural" market or their intellectual ambition. In the early 2000s, for example, a young press without resources such as Les Prairies ordinaires was thus able to pursue a policy of publishing high-quality social science books with the help of the regional government of lle de France, translating a selection of major English-language authors into French (David Harvey, Mike Davis, and Fredric Jameson). However, this kind of small publisher is in direct competition with larger publishing houses, which emphasize the quality of their production. Indeed, it is the "dominant" generalist publishers, such as Gallimard, Le Seuil, or Flammarion who receive most of the funding from the CNL intended for "slow turnover works" (Cartellier 2008) (ie., those with low or moderate sales over several

35. A public body of the ministry of culture, the Centre national du livre was created to support all the actors in the book trade. ADELC was created in 1988 by four publishers (Gallimard, Minuit, Le Seuil, and La Découverte) with the support of the ministry of culture, with the goal of providing technical and financial support for booksellers.

36. In 1981, the Lang law introduced a fixed price for books. This price is set by the publisher, and the retailer-whoever they are-cannot apply a discount of more than $5 \%$. 
“ ouvrages à rotation lente »(Cartellier 2008), c'est-à-dire qui réalisent des ventes faibles ou modérées pendant plusieurs années. La puissance publique valorise en effet l'autonomie des productions, associée au pôle de production restreinte, plutôt que l'indépendance (juridique et financière) des acteurs. Des tensions en découlent : des petits éditeurs indépendants ont contesté les critères d'attribution des aides du CNL et l'opacité du recrutement

par cooptation de ses commissions ${ }^{37}$.

Le problème se pose également au niveau de la librairie, objet d'une attention croissante des pouvoirs publics. La création du label LIR (librairies indépendantes de référence) en 2009 en est une illustration, qui ouvre droit à des exonérations fiscales pour les librairies obéissant à un cahier des charges strict ${ }^{38}$. Le Syndicat de la librairie française (SLF) a cependant obtenu la création d'un second label moins contraignant (Librairies de référence), pouvant inclure les librairies gérées par des éditeurs et les groupements de libraires. $\mathrm{Si}$ ces dernières ne sont pas indépendantes au sens juridique du terme, elles participent du maintien d'un fonds diversifié tout en étant maîtresses de leur assortiment, à la différence des enseignes comme la Fnac. Au-delà des intérêts financiers (l'exonération fiscale), l'enjeu pour le SLF est de préserver un front uni entre des adhérents de taille et de statut hétérogènes. Ce label à deux niveaux illustre encore le découplage entre indépendance et autonomie, et l'enjeu que représente la définition de frontières strictes entre les acteurs ${ }^{39}$.

37. Voir notamment l'ouvrage de Jérôme Vidal (2006: 65).

38. Le label est accordé pour trois ans et concerne 526 librairies au 1 er janvier 2016. Ces dernières doivent remplir un certain nombre de conditions concernant l'indépendance juridique, la taille, l'étendue de leur assortiment, la part des frais de personnel dans leur chiffre d'affaires et l'organisation d'animations culturelles.

39. Une tribune signée par plusieurs responsables de chaînes de librairies conteste l'attribution du label à une minorité de 500 librairies sur les years). Indeed, government authorities prioritize the autonomy of publications associated with the field of restricted production, rather than actors' independence (legal and financial). There are tensions that result from this: small independent publishers have challenged the criteria upon which CNL funds are distributed, and the lack of transparency in recruitment to its commissions. ${ }^{37}$

This issue also affects bookshops, which are the subject of increasing attention by authorities. This can be seen in the creation of the official LIR label (Librairies indépendantes de référence) for independent bookshops in 2009, which provides access to tax exemptions for bookshops that respect strict specifications. ${ }^{38}$ The bookseller trade union, Syndicat de la librairie française (SLF) managed to negotiate the creation of a second, less restrictive label (Librairies de référence) that could include bookshops run by publishers or groups of bookshops. Although the latter are not independent in the legal sense, they are involved in maintaining diversified stock whilst controlling their selection, unlike chains such as Fnac. Beyond the financial advantages (tax exemptions), the goal of the SLF is to maintain a united front between members of different sizes and statuses. This twofold label thus illustrates the disconnection between independence and autonomy and what is at stake in defining strict boundaries between actors. ${ }^{39}$

37. See in particular, Jérôme Vidal book's (2006: 65).

38. The label is awarded for three years and, as of 1 January 2016, concerns 526 bookshops. These establishments must fulfil a certain number of conditions concerning legal independence, size, range of stock, the portion of staff costs in turnover, and the organization of cultural events.

39. Several managers of bookshop chains signed an opinion piece challenging the use of the label for only 500 out of the 3,000 existing bookshops in France and denouncing unfair treatment by the union (SLF) and the ministry of 


\subsection{Le grand public et les pairs}

L'indépendance constitue également une ressource symbolique auprès du public. S'en prévaloir permet en effet de se distinguer sur un marché saturé et peu différencié aux yeux des acheteurs. Le qualificatif entre en résonance avec les attentes des fractions cultivées du public et avec les nouvelles formes de consommation " plus humaines " caractérisées par la proximité et l'authenticité, comme l'atteste le renouveau des commerces indépendants et des artisans entre centres villes (Leblanc 2017). Le succès du mouvement "Indiebound » dans les pays anglophones en est un autre exemple, qui exalte le caractère local des commerces indépendants dans les quartiers gentrifiés, et particulièrement des librairies ${ }^{40}$.

Pour une grande maison généraliste comme Gallimard ( $5^{\mathrm{e}}$ groupe éditorial français avec un chiffre d'affaires consolidé de 432 millions d'euros ${ }^{41}$ ), qui se proclame « premier éditeur français indépendant ${ }^{42} »$, il est essentiel de cultiver la croyance dans l'image de l'éditeur littéraire par excellence puisée dans un passé prestigieux, à l'opposé des logiques financières désincarnées d'un groupe comme Hachette, qui fait d'autant plus office de repoussoir qu'il est objectivement proche. À l'inverse, pour des petites structures dominées sur le plan économique, valoriser leur indépendance et le caractère alternatif de leur pratique sera le moyen de gagner en capital symbolique et donc d'attirer des auteurs et des lecteurs. De par son caractère flou,

3000 existantes en France, dénonçant une inégalité de traitement de la part du syndicat (SLF) et du ministère de la Culture ([2017] « LIR, un label qui n'est plus adapté aux périls qui guettent la librairie française ». Livres Hebdo, $\mathrm{n}^{\circ} 1154,15$ décembre).

40. [En ligne] [consulté le 5 avril 2017].

41. Fabrice Piault, «Les 200 premiers éditeurs français », op. cit

42. [En ligne] [consulté le 5 avril 2017].

\subsection{The General Public and Industry Peers}

Independence is also a symbolic resource in the eyes of the public. Obtaining it means being able to set oneself apart in the eyes of buyers, in a market that is saturated and lacking differentiation. The adjective resonates with the expectations of more cultivated fractions of the public and with new "more human" forms of consumerism based on authenticity and local services. This can be seen in the renewal of independent and artisan shops in town centres (Leblanc 2017). The success of the "Indiebound" movement in the English-speaking world is another example of this, exalting the local nature of independent shops in gentrified areas, and bookshops in particular. ${ }^{40}$

For a major generalist publisher such as Gallimard (the fifth largest publishing group in France with a consolidated turnover of 432 million euros ${ }^{41}$ ) which calls itself the "first independent French publisher," 42 it is essential to cultivate a belief in the image of the literary publisher par excellence. To do this they draw on a prestigious past, directly opposed to the disembodied financial logics of a group like Hachette-which is all the better as a foil because it is objectively close. Conversely, for small structures that are economically subjugated, valuing independence and the alternative nature of their activity is a way to gain symbolic capital and attract authors and readers. Because of its vague nature, independence thus brings together the various interests of actors situated at opposite positions of the editorial field, who

culture ('LIR, un label qui n'est plus adapté aux périls qui guettent la librairie française" [2017]. Livres Hebdo, 1154, 15 December).

40. [Online] [accessed on 5 April 2017].

41. Fabrice Piault (2018). "Les 200 premiers éditeurs français." Livres Hebdo, 1179, 22 June.

42. [Online] [accessed on 5 April 2017]. 
l'indépendance fédère ainsi les intérêts d'acteurs situés en des points opposés du champ éditorial, lesquels se rejoignent dans la revendication d'une autonomie intellectuelle, quelle que soit leur envergure économique. Une telle plasticité n'est pas sans poser problème, en particulier sur le terrain de la reconnaissance entre pairs, troisième terrain d'enjeux identifié.

La virulence des luttes de classement et la nécessité d'opérer des rappels à l'ordre en faisant le tri entre « vrais » indépendants (incarnant une forme de pureté et de vertu) et "pseudo " indépendants, caractérisés par les compromissions et la recherche du profit, illustre l'importance de l'enjeu. Plusieurs ouvrages publiés par des acteurs du monde éditorial ont réactivé cette thématique, en s'efforçant de réaffirmer les formes légitimes de la pratique selon la logique des avant-gardes artistiques: ethos artisanal, investissement sur le mode vocationnel, refus de toute forme d'opportunisme économique. Ainsi l'ex-responsable de la maison d'édition d'essais engagés Agone appelle-t-il à faire la différence entre "les entreprises régies par une logique de croissance par acquisition » et «les producteurs de livres qui ne soient pas tout à fait un objet de consommation comme un autre " (Discepolo 2011 : 17-18), bien que la frontière entre les deux univers relève surtout de critères d'ordre moral. Autour de l'opposition entre « vrais » et « faux ", se rejoue finalement la division traditionnelle entre les acteurs du pôle de production restreinte, qui évoquent le nomos de l'art pour l'art en se référant à un état antérieur, plus pur, du champ, et ceux du pôle de grande diffusion, qui tendent à se reconnaître dans une définition entrepreneuriale et dépolitisée de l'indépendance. Ces jeux de classification recouvrent par ailleurs des enjeux économiques dans la mesure où les petites structures jouent traditionnellement un rôle exploratoire, développant les auteurs ou les formats qui seront potentiellement consacrés et récupérés come together in claiming intellectual autonomy, regardless of their economic status. However, this malleability raises certain problems, particularly in terms of recognition between peers, which is the third issue at stake here.

The virulence of the struggles for classification and the need to issue some calls to order in distinguishing "true" independents (who incarnate a form of purity and virtue) from "pseudo" independents (characterized by their compromising behaviour and search for profit) demonstrate the importance of this issue. Several texts published by actors in the publishing industry have reactivated this theme, attempting to reaffirm the legitimate forms of the practice according to the logic of the artistic avant-garde: artisanal ethos, vocational investment, and refusal of any form of economic opportunism. The former director of Agone publishing house, which focuses on political essays, calls for a distinction between "businesses that are governed by a logic of growth through acquisition" and "those who produce books that are not just like any other commodity" (Discepolo 2011: 17-18); although the distinction between the two is above all based on moral criteria. The opposition between "true" and "false" independents also reflects the traditional opposition between the actors in the field of restricted production, who evoke the nomos of art for art's sake by referring to a previous, purer state of the field, and the actors of large-scale, mass production, who tend to identify with an entrepreneurial and depoliticized definition of independence. These classification role plays cannot be disconnected from economic issues to the extent that small structures traditionally play an exploratory role, developing authors or formats that will potentially be taken up and developed later by larger publishing houses. In this respect we can cite the philosopher Slavoj Žižek's increasing shift from small 
par les maisons plus importantes. On peut évoquer à cet égard le passage progressif du philosophe Slavok Žižek de petites structures éditoriales marginales à des maisons prestigieuses à partir des années $2000^{43}$ ou, plus récemment, le débauchage de Fred Vargas, autrice de polars à succès, par Flammarion ${ }^{44}$

Si les tentatives de clarification des critères de l'indépendance par les acteurs trahissent l'exacerbation des positions au sein d'un champ éditorial fragilisé par les mutations technologiques et financières, elles reflètent également une banalisation et une dilution de sens. Un signe en est l'appropriation du terme par des acteurs jouant sur l'ambiguïté de leur situation en se présentant comme indépendants et alternatifs tout en bénéficiant de l'appui d'une structure plus importante. Les réticences croissantes de certains acteurs vis-à-vis d'un terme ayant perdu de son pouvoir de distinction ne sont sans doute pas étrangères à ce type de phénomène, alors même que le terme « autonomie » est remis en avant, dans une acception quasi savante. Ainsi cet éditeur de littérature et de poésie, en faisant référence au contexte économique actuel :

J'en suis venu à me dire que, plutôt que d'édition indépendante, peut-être serait-il plus juste de parler d'édition autonome [...] au sens d'une détermination à se donner sa propre loi, à décider de ses propres modalités de fonctionnement ${ }^{45}$.

43. D'abord traduit par de petits éditeurs comme Navarin, Points hors ligne, Nautilus ou Amsterdam, Slavok Žižek est majoritairement publié, à partir des années 2000, par de grands éditeurs généralistes (Flammarion, Le Seuil, Fayard). Sur les enjeux de traduction pour les petites maisons, voir le livre de Sophie Noël (2012b).

44. Fred Vargas était publiée depuis 20 ans par la maison indépendante Vivianne Hamy.

45. Intervention de Benoît Casas (éditions Nous) lors du débat « Territoires critiques » organisé par le CEMTI le 4 juin 2014. marginal publishers to prestigious publishing houses from the $2000 \mathrm{~s},{ }^{43}$ or more recently, Flammarion's poaching of Fred Vargas and her successful crime novels. ${ }^{44}$

Although attempts to clarify the criteria of independence demonstrate the growing polarization within an editorial field upset by technological and financial changes, they also reflect the increasing banality and dilution of the term's meaning. The fact that certain actors are able to appropriate this adjective in order to play on the ambiguities of their situation, presenting themselves as both independent and alternative while benefiting from the support of a large structure, is a clear indication of this. The increasing reticence of certain actors to use a term they see as having lost its discriminatory power is undoubtedly related to this phenomenon. They will therefore switch to the term "autonomy," used in a quasisociological sense. One poetry and literature publisher had this to say, in reference to the current economic context:

I've ended up telling myself that perhaps it would be more accurate to talk about autonomous publishing rather than independent publishing [...] in the sense of a resolution to make one's own rules, decide one's own modes of functioning. ${ }^{45}$

43. Slavoj Žižek was first translated by small publishers such as Navarin, Points hors ligne, Nautilus, and Amsterdam, but since the 2000s he has been primarily published by large generalist publishers (Flammarion, Le Seuil, Fayard). On the subject of translation for small publishing houses see Sophie Noël's book (2012b).

44. For the past twenty years, Fred Vargas had been published by the independent publishing house Vivianne Hamy.

45. Presentation by Benoît Casas (Editions Nous) during the debate "Territoires critiques" (critical landscapes) organized by CEMTI 4 June 2014 
L'usage de l'épithète " autonome " dans un contexte non savant renvoie ici à une forme atténuée et modeste du terme, recentrée sur le versant intellectuel de l'activité, au détriment des éléments constitutifs de l'indépendance économique, perçue comme illusoire dans le contexte actuel. Ce choix de l'autonomie en tant que substitut plus précis et plus réaliste que «l'attrape tout » de l'indépendance est peut-être le signe d'une reconfiguration des titres entre acteurs dominants et dominés du champ éditorial : les premiers n'accordent aux seconds que la lucidité d'une indépendance très relative, présentée comme un « espace » ou, comme il est tentant de l'écrire, une « espèce » d'autonomie au sein d'un océan de dépendances.

\section{Conclusion}

On voit à quel point les jeux de sens autour des notions d'indépendance et d'autonomie sont complexes et évolutifs dans le secteur du livre. Plusieurs oppositions classiques viennent en effet s'agréger et se combiner autour de ces termes «valises », qui ne se recoupent que partiellement : opposition entre petites et grosses structures, entre pôle de production restreinte et pôle de grande production, ou encore entre avant-gardes et acteurs consacrés. Au terme de cette cartographie des luttes de classification aux enjeux hétérogènes, il apparaît que les catégories d'édition et de librairie indépendantes renvoient à une réalité sociale aussi floue que celles qui les ont précédées, telles que l'édition engagée ou la librairie traditionnelle. L'ambigüité est en effet constitutive de ces catégories dans la mesure où, comme le souligne Frédéric Lebaron (1997) à propos de la Banque de France, l'indépendance est une fiction sociale, particulièrement efficace dans un univers comme celui du livre où les croyances quant au statut « à part " des biens produits sont fortes et anciennes.
The use of the adjective "autonomous" reflects an attenuated and modest understanding of the word, focused on the intellectual aspect of the activity to the detriment of elements relating to economic independence, which are considered illusory in the current context. The choice of autonomy as a more specific and more realistic replacement for the catch-all term independence is perhaps the sign of a reconfiguration of terminology between dominant and dominated actors in the editorial field. The former allow the latter only the lucidity to perceive their very relative independence, presented as an island of autonomy within an ocean of dependency.

\section{Conclusion}

We can see just how complex and changing the stakes around notions of independence and autonomy within the publishing industry are. Several traditional oppositions aggregate and combine around these "carryall" terms, which only partially overlap. There is the opposition between small and large structures, between the pole of restricted production and that of large-scale production, or between avant-garde and established structures. In light of this cartography of the struggles over classification and their diverse issues, it seems that the categories of independent publishing and bookselling reflect a social reality that is as vague as the categories that preceded them, such as that of radical publishing or traditional bookshops. Ambiguity is in fact constitutive of these categories to the extent that, as Frédéric Lebaron (1997) emphasized in relation to the Banque de France, France's central bank, independence is a social fiction. However, it is a fiction that is particularly useful in a sphere such as the book trade in which there has long been a widespread belief in the "special" nature of these goods. 
Une telle fiction permet de masquer les contradictions propres aux espaces de production symbolique qui doivent « faire commerce de ce qui n'a pas de prix ", tout en incarnant un modèle désirable et un supplément d'âme face à la perte d'autonomie de ces dernières décennies. Pour autant, tous les acteurs ne peuvent s'en saisir de manière légitime. L'usage extensif du terme " indépendant " par les acteurs du secteur du livre, au-delà de la démonétisation qu'il induit, peut paradoxalement être perçu comme le signe d'une régression sur le terrain de l'autonomie au sens sociologique du terme. L'émergence d'une revendication indigène de l'autonomie, minorée par rapport à l'acception savante puisqu'elle se réduit à une indépendance des contenus déconnectée de l'indépendance des structures, en est l'un des symptômes. Ce dernier est d'autant plus préoccupant qu'il entérine la séparation de deux réalités dont on sait depuis au moins le xixe siècle qu'elles sont fortement

imbriquées.

Sophie Noël

Université Paris 13 - Laboratoire de sciences de l'information et de la communication (Labsic)/Centre européen de sociologie et de science politiqueCentre de sociologie européenne (Cessp-CSE)

\section{Références bibliographiques}

Association l'Autre Livre (2005). Pour l'édition indépendante. Paris.

BouRdieu Pierre (1992). Les Règles de l'art. Paris, Seuil.

BOURDIEU Pierre (1999). " Une révolution conservatrice dans l'édition ». Actes de la recherche en sciences sociales, 126-127 : 3-28.

BOUTET Josiane (2010). Le Pouvoir des mots. Paris, La Dispute.
This fiction provides a mask for the contradictions inherent in the spaces of symbolic production which must "buy and sell what is priceless," while also incarnating a desirable model and a degree of soul in a context of waning autonomy over recent decades. However, not all actors can legitimately lay claim to it. The extensive use of the term "independent," beyond the demonetization that it implies, can paradoxically be seen as a sign of reduced autonomy, in the sociological sense of the word. The emerging usage of the term autonomy by actors within the sector, somewhat minimized in comparison to its intellectual usage because it refers to independence in content that is disconnected from the economic independence of the structures themselves, is a symptom of this. This is all the more disquieting in that it consolidates the separation of two realities that, since the nineteenth century at least, we know to be deeply interconnected.

Sophie Noë

Université Paris 13 - Laboratoire de sciences de l'information et de la communication (Labsic)/Centre européen de sociologie et de science politiqueCentre de sociologie européenne (Cessp-CSE)

\section{References}

Association l'Autre Livre (2005). Pour l'édition indépendante. Paris.

BOURDIEU Pierre (1996). The Rules of Art. Genesis and Structure of the Literary Field. English translation from French by Susan Emanuel. Cambridge, Polity Press.

BOURDIEU Pierre (2008). "A conservative revolution in publishing." English translation from French by Ryan Fraser. Translation Studies, 1(2): 123153. 
Bouvalst Jean-Marie (1993). « Crise et mutations dans l'édition française ». Cahier de l'économie du livre, hors-série, 3.

CARACO Benjamin (2017). « L'Association en toute indépendance. Distribuer, diffuser, distinguer la bande dessinée en France ». In Alexandre Olivier, Noël Sophie, Pinto Aurélie (dir.). Culture et (in)dépendance. Les enjeux de l'indépendance dans les industries culturelles. Berne, Peter Lang : 69-85.

CARTELLIER Dominique (2008). «Indépendance éditoriale et dispositifs d'aide à la publication ». Communication \& langages, $156: 63-73$.

ChARLE Christophe (1990). Naissance des intellectuels. Paris, Minuit.

CHIAPELLO Ève (1998). Artistes versus managers. Le management culturel face à la critique artistique. Paris, Métailié.

Discepolo Thierry (2011). La Trahison des clercs. Marseille, Agone.

DuBoıs Vincent (1999). La Politique culturelle. Genèse d'une catégorie d'intervention publique. Paris, Belin.

DuVAL Julien \& Garcia Marie-France (2012). « Les enjeux symboliques des échanges économiques ». Revue française de socio-économie, 10 13-28.

Duval Julien (2016). Le Cinéma au $x x^{e}$ siècle. Entre loi du marché et règles de l'art. Paris, CNRS Éditions.

DOUYĖRE David (2008). «Indépendance économique et politique éditoriale des encyclopédies de Saint-Simon à Wikipédia ». Communication \& langages, $156: 37-51$.
Boutet Josiane (2010). Le Pouvoir des mots. Paris, La Dispute.

BouvaIST Jean-Marie (1993). "Crise et mutations dans l'édition française." Cahier de l'économie du livre, special issue, 3.

CARACO Benjamin (2017). "L'Association en toute indépendance. Distribuer, diffuser, distinguer la bande dessinée en France." In Alexandre Olivier, Noël Sophie, Pinto Aurélie (eds.). Culture et (in)dépendance. Les enjeux de l'indépendance dans les industries culturelles. Berne, Peter Lang: 69-85.

Cartellier Dominique (2008). "Indépendance éditoriale et dispositifs d'aide à la publication." Communication \& langages, 156: 63-73.

CHARLE Christophe (2015). Birth of the Intellectuals: 1880-1900. English translation from French by G.M. Goshgarian \& David Fernbach. Cambridge, Polity Press.

CHIAPELLO Ève (1998). Artistes versus managers. Le management culturel face à la critique artistique. Paris, Métailié.

Discepolo Thierry (2011). La Trahison des clercs. Marseille, Agone.

DuBoIs Vincent (1999). La Politique culturelle. Genèse d'une catégorie d'intervention publique. Paris, Belin.

DUVAL Julien \& Garcia Marie-France (2012). "Les enjeux symboliques des échanges économiques." Revue française de socio-économie, 10: 13-28.

Duval Julien (2016). Le Cinéma au $x x^{e}$ siècle. Entre loi du marché et règles de l'art. Paris, CNRS Éditions.

DOUYĖRE David (2008). "Indépendance économique et politique éditoriale des encyclopédies de Saint-Simon à Wikipédia." Communication \& langages, 156: 37-51. 
HABRAND Tanguy (2016). «Indépendance ». In Glinoer Anthony \& Denis Saint-Amand (dir.), Le Lexique socius. [En ligne] [consulté le 20 mars 2017].

HABRAND Tanguy (2017). « My major is indie. Les stratégies de récupération du label "indépendant" par les groupes d'édition ». In Alexandre Olivier Noël Sophie, Pinto Aurélie (dir.), Culture et (in)dépendance. Les enjeux de l'indépendance dans les industries culturelles. Berne, Peter Lang : 193-205.

HAGE Julien (2016). " La génération des éditeurs protagonistes de la décolonisation. Radicalités, rigueurs et richesses de l'engagement éditorial ». Bibliodiversity. [En ligne] [consulté le 10 avril 2017].

Hesmondhalgh David (1999). " Indie, the institutional politics and aesthetics of a popular music genre ». Cultural Studies, 13(1) : 34-61.

HibBet Ryan (2005). « What is indie rock? ». Popular Music and Society, $28: 55-77$.

JeanPierRe Laurent \& RouefF Olivier (dir.) (2014). La Culture et ses intermédiaires dans les arts, le numérique et les industries créatives. Paris, Éditions des archives contemporaines.

JouHAud Christian (2000). Les Pouvoirs de la littérature. Histoire d'un paradoxe. Paris, Gallimard.

LEBARON Frédéric (1997). " Les fondements sociaux de la neutralité économique ». Actes de la recherche en sciences sociales, 116-117 : 6990.

LEBLANC Frédérique (1998). Libraire, un métier ?. Paris, L'Harmattan.

Leblanc Frédérique (2017) (dir.). « Gens de commerce ». Ethnologie française, 165.
HABRAND Tanguy (2016). "Indépendance." In Glinoer Anthony \& Saint-Amand Denis (eds.). Le Lexique socius. [Online] [accessed 20 March 2017].

HABRAND Tanguy (2017). "My major is indie. Les stratégies de récupération du label 'indépendant' par les groupes d'édition." In Alexandre Olivier Noël Sophie, Pinto Aurélie (eds.). Culture et (in)dépendance. Les enjeux de l'indépendance dans les industries culturelles. Berne, Peter Lang: 193-205.

HAGE Julien (2016). "La génération des éditeurs protagonistes de la décolonisation. Radicalités, rigueurs et richesses de l'engagement éditorial." Bibliodiversity. [Online] [accessed on 10 April 2017].

HesmondHALGH David (1999). "Indie, the institutional politics and aesthetics of a popular music genre." Cultural Studies, 13(1): 34-61.

HiBBET Ryan (2005). "What is indie rock?" Popular Music and Society, 28 55-77.

JeAnPIERRE Laurent \& RouefF Olivier (eds.) (2014). La Culture et ses intermédiaires dans les arts, le numérique et les industries créatives. Paris, Édition des archives contemporaines.

JouHAud Christian (2000). Les Pouvoirs de la littérature. Histoire d'un paradoxe. Paris, Gallimard.

LeBARON Frédéric (1997). "Les fondements sociaux de la neutralité économique." Actes de la recherche en sciences sociales, 116-117: 6990

LEBLANC Frédérique (1998). Libraire, un métier? Paris, L’Harmattan.

Leblanc Frédérique (2017) (ed.). "Gens de commerce." Ethnologie française, 165 
LEBLANC Frédérique \& SOREL Patricia (2008). Histoire de la librairie française. Paris, Éditions du cercle de la librairie.

LEGENDRE Bertrand \& ABEnsouR Corinne (2007). Regards sur l'édition (1). Les petits éditeurs : situations et perspectives. Paris, La Documentation française.

LEHEMBRE Sébastien (2017). « Les ressorts nationaux d'une définition transnationale de l'éditeur indépendant ». In Alexandre Olivier, Noël Sophie, Pinto Aurélie (dir.). Culture et (in)dépendance. Les enjeux de l'indépendance dans les industries culturelles. Berne, Peter Lang : 163177.

MAUger Gérard (2007). Droits d'entrée. Modalités et conditions d'accès aux univers artistiques. Paris, Maison des sciences de l'Homme.

MILLER Laura J. (2006). Reluctant capitalists. Bookselling and the culture of consumption. Chicago, University of Chicago Press.

MolLIER Jean-Yves (2015a). Une autre histoire de l'édition française. Paris, La fabrique.

MolLIER Jean-Yves (2015b). Hachette, le géant aux ailes brisées. Paris, Éditions de l'Atelier.

NEWMAN Michaël Z. (2009). « Indie culture : in pursuit of the authentic autonomous alternative ». Cinema Journal, 48 (3) : 16-34.

NoËL Sophie (2012a). L'Édition indépendante critique. Engagements politiques et intellectuels. Villeurbanne, Presses de l'Enssib.

NoËL Sophie (2012b). « L'engagement par la traduction. Le rôle des petits éditeurs indépendants dans l'importation des ouvrages de sciences humaines ». In Sapiro Gisèle (dir.), Traduire la littérature et les sciences humaines. Conditions et obstacles. Paris, La Documentation française : 273-295.
LEBLANC Frédérique \& SoREL Patricia (2008). Histoire de la librairie française. Paris, Éditions du Cercle de la librairie.

LEgendRe Bertrand \& Abensour Corinne (2007). Regards sur l'édition (1). Les petits éditeurs: situations et perspectives. Paris, La Documentation française.

LEHEMBRE Sébastien (2017). "Les ressorts nationaux d'une définition transnationale de l'éditeur indépendant." In Alexandre Olivier, Noë Sophie, Pinto Aurélie (eds.). Culture et (in)dépendance. Les enjeux de l'indépendance dans les industries culturelles. Berne, Peter Lang: 163177.

MAuger Gérard (2007). Droits d'entrée. Modalités et conditions d'accès aux univers artistiques. Paris, Maison des sciences de l'homme.

MilLeR Laura J. (2006). Reluctant Capitalists. Bookselling and the Culture of Consumption. Chicago, University of Chicago Press.

MolLIER Jean-Yves (2015a). Une autre histoire de l'édition française. Paris, La fabrique.

MolLIER Jean-Yves (2015b). Hachette, le géant aux ailes brisées. Paris, Éditions de l'Atelier.

NeWman Michaël Z. (2009). "Indie culture: in pursuit of the authentic autonomous alternative." Cinema Journal, 48(3): 16-34.

NoËL Sophie (2012a). L'Édition indépendante critique. Engagements politiques et intellectuels. Villeurbanne, Presses de l'Enssib.

NoËL Sophie (2012b). "L'engagement par la traduction. Le rôle des petits éditeurs indépendants dans l'importation des ouvrages de sciences humaines." In Sapiro Gisèle (ed.), Traduire la littérature et les sciences humaines. Conditions et obstacles. Paris, La Documentation française: 273-295. 
NoËL Sophie (2018). « Le petit commerce de l'indépendance. Construction matérielle et discursive de l'indépendance en librairie ». Sociétés contemporaines, $111: 45-70$.

OZANNE Jean-Marie (2008). « Évolution de l'identité professionnelle des libraires ». In Leblanc Frédérique \& Sorel Patricia (dir.). Histoire de la librairie française. Paris, Éditions du Cercle de la librairie : 363-364.

PINHAS Luc (1998). «Évolution et diversité de la librairie "traditionnelle" ». In Leblanc Frédérique \& Sorel Patricia (dir.), Histoire de la librairie française. Paris, Cercle de la librairie : 596-614.

RoBIN Christian (2008). « La notion d'indépendance éditoriale, aspects financiers, organisationnels et commerciaux ». Communication \& langages, $156: 53-62$.

ROUET François (2007). Le Livre, mutations d'une industrie culturelle. Paris, La Documentation française.

SAPIRO Gisèle \& BoKOBZA Anaïs (2008). « L'essor des traductions littéraires en français ». In Translatio. Le marché de la traduction en France à l'heure de la mondialisation. Paris, CNRS Éditions : 145-173.

SCHIFFrIN André (1999). L’Édition sans éditeurs. Paris, La fabrique.

SIMONIN Anne (1994). Les Éditions de Minuit, 1942-1955, le devoir d'insoumission. Paris, Imec.

SIMONIN Anne (2004). « Le catalogue de l'éditeur, un outil pour l'histoire : l'exemple des éditions de Minuit ». xxe siècle, Revue d'histoire, 81 : 119129.

StIGLER George (1968). The Organization of Industry. Richard D. Irving, Homewood.
NoËL Sophie (2018). "Le petit commerce de l'indépendance. Construction matérielle et discursive de l'indépendance en librairie." Sociétés contemporaines, 111: 45-70.

OzANNE Jean-Marie (2008). "Évolution de l'identité professionnelle des libraires." In Leblanc Frédérique \& Sorel Patricia (eds.). Histoire de la librairie française. Paris, Éditions du Cercle de la librairie: 363-364.

PINHAS Luc (1998). "Évolution et diversité de la librairie 'traditionnelle'." In Leblanc Frédérique \& Sorel Patricia (eds.) Histoire de la librairie française. Paris, Cercle de la librairie: 596-614.

RoBIN Christian (2008). "La notion d'indépendance éditoriale, aspects financiers, organisationnels et commerciaux." Communication \& langages, 156: 53-62.

ROUET François (2007). Le Livre. Mutations d'une industrie culturelle. Paris, La Documentation française.

SAPIRO Gisèle \& BOKOBZA Anaïs (2008). "L'essor des traductions littéraires en français." In Translatio, Le marché de la traduction en France à l'heure de la mondialisation: 145-173.

Schiffrin André (2000). The Business of Books. How the International Conglomerates Took Over Publishing and Changed the Way We Read. London, Verso.

SimONIN Anne (1994). Les Éditions de Minuit, 1942-1955. Le devoir d'insoumission. Paris, Imec.

SIMONIN Anne (2004). "Le catalogue de l'éditeur, un outil pour l'histoire: l'exemple des éditions de Minuit." $x x^{e}$ siècle, Revue d'histoire, 81: 119129. 
Tesniere Valérie (2001). Le Quadrige 1860-1968. Paris, Presses Universitaires de France (PUF).

Thompson John B. (2005). Books in the Digital Age. Cambridge, Polity Press.

VIDAL Jérôme (2006). Lire et penser ensemble. Sur l'avenir de l'édition indépendante. Paris, Éditions Amsterdam.
StIGLER George (1968). The Organization of industry. Richard D. Irving, Homewood.

TESNIERE Valérie (2001). Le Quadrige 1860-1968. Paris, Presses Universitaires de France.

Thompson John B. (2005). Books in the Digital Age. Cambridge, Polity Press.

VIDAL Jérôme (2006). Lire et penser ensemble. Sur l'avenir de l'édition indépendante. Paris, Éditions Amsterdam. 